\title{
Multiple Adhesin-Like Functions of Xanthomonas oryzae pv. oryzae Are Involved in Promoting Leaf Attachment, Entry, and Virulence on Rice
}

\author{
Amit Das, Nandini Rangaraj, and Ramesh V. Sonti \\ Centre for Cellular and Molecular Biology, Council of Scientific and Industrial Research, Uppal Road, Hyderabad-500 007, \\ A.P., India
}

Submitted 2 June 2008. Accepted 10 September 2008.

\begin{abstract}
Xanthomonas oryzae pv. oryzae is the causal agent of bacterial blight of rice. We have used enhanced green fluorescent protein-tagged $X$. oryzae pv. oryzae cells in conjunction with confocal microscopy to monitor the role of several adhesin-like functions in bacterial adhesion to leaf surface and early stages of leaf entry. Mutations in genes encoding either the Xanthomonas adhesin-like protein A (XadA) or its paralog, Xanthomonas adhesin-like protein B (XadB), as well as the $X$. oryzae pv. oryzae homolog of Yersinia autotransporter-like protein $\mathrm{H}$ (YapH), exhibit deficiencies in leaf attachment or entry. A mutation in the $X$. oryzae pv. oryzae pilQ gene, which is predicted to encode the type IV pilus secretin, appears to have no effect on leaf attachment or entry. The $x_{a d A^{-}}$mutant is deficient in the ability to cause disease following surface inoculation while the XadB, YapH, and PilQ functions are less important than XadA for this process. The $\mathrm{xadA}^{-}$and $\mathrm{xadB}^{-}$mutants have no effect on virulence following wound inoculation whereas the $\mathrm{yapH}^{-}$ and pil $^{-}$mutants are always virulence deficient following wound inoculation. Overall, these results indicate that multiple adhesin-like functions are involved in promoting virulence of $X$. oryzae pv. oryzae, with preferential involvement of individual functions at different stages of the disease process.
\end{abstract}

Bacterial attachment to host surfaces is mediated by specific adhesins. Bacterial adhesins are often surface-associated proteins which dock and bind to host surface receptors. These proteinaceous adhesins are broadly classified into two major groups: afimbrial or nonfimbrial and fimbrial adhesins (Soto and Hultgren 1999). Afimbrial adhesins are made up of single proteins whereas fimbrial adhesins are multiprotein structures.

In Dickeya dadantii (synonym Erwinia chrysanthemi), a mutation in the hecA gene (encoding an afimbrial adhesin belonging to the filamentous hemagglutinin family) causes reduced virulence on tobacco when inoculation is done without wounding and also results in reduced attachment and aggregate formation on tobacco leaves (Rojas et al. 2002). In Xylella fastidiosa, the fimbrial mutants fim $A^{-}$and $f i m F^{-}$, as well as the afimbrial mutants $x a d A^{-}$and $h x f B^{-}$, exhibit reduced virulence on grape plants (Feil et al. 2007). The authors have proposed a

Corresponding author: Ramesh V. Sonti; Telephone: +91-40-27192577; Fax: +91-40-27160591; E-mail: sonti@ccmb.res.in; rvsonti@yahoo.com

* The $\boldsymbol{e}$-Xtra logo stands for "electronic extra" and indicates that three supplemental tables and two supplemental figures are published online. model which suggests that fimbrial adhesins are involved in cell-to-cell aggregation while afimbrial adhesins contribute to initial surface binding. Studies in Agrobacterium tumefaciens have indicated that an acidic polysaccharide (Reuhs et al. 1997), a $\beta$-1-2 glucan (Puvanesarajah et al. 1985), and cellulose (Matthysse 1983) play a role in adhesion to host surfaces. Also, many members of the family Rhizobiaceae (including $A$. tumefaciens) mediate direct attachment to plant root hair cells through a $\mathrm{Ca}^{2+}$-dependent adhesin called rhicadhesin (Smit et al. 1989).

The role of type IV pilus (a fimbrial adhesin) in adhesion and virulence of plant-pathogenic bacteria has been investigated in several studies. In Ralstonia solanacearum, a mutation in the pilA gene, which encodes type IV pilin, has been shown to inhibit the capability of polar attachment to cells in a tobacco suspension culture as well as to tomato roots (Kang et al. 2002). A mutation in the pilQ gene, which encodes type IV pilus secretin (Drake and Koomey 1995), has been shown to be associated with reduced virulence in tomato plants (Kang et al. 2002; Liu et al. 2001). In X. fastidiosa, mutation in the pilQ gene as well as in the pilB gene (the later encodes nucleotidebinding protein involved in providing energy for pilin translocation and assembly) has been shown to affect colonization and upstream migration of the bacteria in xylem vessels (Meng et al. 2005). Pili-like structures have been shown to be involved in the attachment of Bradyrhizobium japonicum to soybean roots (Vesper and Bauer 1986). Type IV pilus of X. campestris pv. hyacinthi has been suggested to play a role in attachment to stomata of hyacinth leaves (van Doorn et al. 1994). Stomatal attachment of Pseudomonas syringae pv. phaseolicola in bean leaves has been reported to be mediated by pili (Romantschuk and Bamford 1986). However, type IV pilus has been reported to play no role in the attachment of either $P$. syringe pv. tomato DC3000 (Roine et al. 1998) or Xanthomonas campestris pv. vesicatoria to tomato leaves (Ojanen-Reuhs et al. 1997).

$X$. oryzae pv. oryzae, the causal agent of bacterial blight of rice, enters rice leaves primarily through hydathodes, which are natural openings situated at the tips and margins of rice leaves (Mew et al. 1984; Tabei 1967). Very little information is available about the functions that are used by $X$. oryzae $\mathrm{pv}$. oryzae, as well as other xanthomonads, to attach to host tissues. The Xanthomonas adhesin-like protein A (XadA) of $X$. oryzae pv. oryzae is a large $(1,265$ amino acids [aa]), outermembrane-located protein that shows sequence homology with well-characterized adhesins such as Yersinia adhesin A (YadA) of Yersinia spp. (Ray et al. 2002). The XadA protein of $X$. oryzae pv. oryzae has been shown to be required for optimal 
virulence upon surface inoculation (i.e., infection primarily through hydathodes) and has been predicted to be a putative adhesin. The genome sequences of three strains of $X$. oryzae pv. oryzae (KACC10331, MAFF311018, and PXO99A) indicate the presence of multiple adhesin-like functions in their genomes (Lee et al. 2005; Ochiai et al. 2005; Salzberg et al. 2008). One such adhesin-like function is a paralog of XadA, designated Xanthomonas adhesin-like protein B (XadB). Another candidate adhesin-like function of $X$. oryzae pv. oryzae is an ortholog of Yersinia autotransporter protein $\mathrm{H}$ (YapH), which is predicted to be an autotransporter adhesin. The genome sequences of $X$. oryzae pv. oryzae strains also reveal the presence of several genes which are predicted to encode different components of type IV pilus, of which one gene exhibits homology with the pilQ gene of various plant- and animal-pathogenic bacteria.

The objective of the present study is to understand the role of $\mathrm{XadA}, \mathrm{XadB}, \mathrm{YapH}$, and type IV pilus in rice leaf attachment or entry and virulence of $X$. oryzae pv. oryzae. Mutations were generated in the $x a d B, y a p H$, and pilQ genes of $X$. oryzae pv. oryzae by $\mathrm{pK} 18 \mathrm{mob}-\mathrm{mediated}$ gene disruption. These mutants, along with the previously isolated transposon insertion mutants of the xadA gene (Ray et al. 2002), were used to assess the role of these candidate adhesin-like functions in leaf attachment/entry and virulence of $X$. oryzae pv. oryzae using enhanced green fluorescent protein (EGFP)-tagged $X$. oryzae pv. oryzae cells and confocal microscopy as well as standard virulence assays.

\section{RESULTS}

\section{Identification of adhesin-like functions \\ in the genome of $X$. oryzae pv. oryzae.}

In silico analysis indicates that several adhesin-like functions are encoded in the genome of $X$. oryzae pv. oryzae. A BLAST search with the previously described xadA gene reveals the presence of a paralog (XOO0681 in the genome of $X$. oryzae pv. oryzae KACC10331) (Lee et al. 2005), which is predicted to encode a 1,027-aa-long outer membrane protein. This predicted protein is referred to as $\mathrm{XadB}$. There is approximately $40 \%$ identity and $50 \%$ similarity between the predicted sequences of the XadA and XadB proteins of $X$. oryzae pv. oryzae KACC110331. Sequence analysis of XadB indicates the presence of several predicted domains or repeats such as an autotransporter-like C-terminal region (similar to YadA), hemagglutinin motif (similar to Haemophilus influenzae Hia autotransporter adhesin), and Hep_hag repeats (similar to Burkholderia autotransporter hemaglutinin [BuHA]-like proteins). These features are consistent with the possibility that this protein might be an adhesin.

Another adhesin-like function in the $X$. oryzae pv. oryzae genome is a homolog of the Yersinia gene yapH, which is predicted to encode an autotransporter adhesin and in which a mutation affects virulence in a $C$. elegans infection model (Styer et al. 2005). X. oryzae pv. oryzae YapH (XOO2380 in X. oryzae pv. oryzae KACC10331, 2,732 aa) exhibits $40 \%$ similarity and $25 \%$ identity to Yersinia pestis YapH. The predicted protein sequence of $X$. oryzae pv. oryzae $\mathrm{YapH}$ also has several sequence features which suggest that it might be an adhesin. These include a $\mathrm{C}$-terminal autotransporter $\beta$-domain, filamentous hemagglutinin motifs, and several autotransporter associated $\beta$-strand repeats.

The genome of $X$. oryzae pv. oryzae also harbors several genes that are predicted to be involved in the biogenesis of type IV pilus (Lee et al. 2005; Ochiai et al. 2005; Salzberg et al. 2008). The XOO1161 gene (in X. oryzae pv. oryzae KACC10331) is predicted to encode PilQ, the type IV pilus secretin. The predicted protein product of XOO1161 is 673 aa long and exhibits $33 \%$ identity and 53\% similarity to the PilQ protein of Neisseria gonorrhoeae. Nonpolar mutations were generated (as described) in the $x a d B, y a p H$, and pilQ genes of $X$. oryzae pv. oryzae by homologous plasmid integration.

\section{An assay for monitoring leaf attachment and entry by $X$. oryzae pv. oryzae.}

In order to understand the role of different adhesin-like functions of $X$. oryzae pv. oryzae in early stages of leaf attachment and entry, an assay was developed which involved using EGFP-tagged $X$. oryzae pv. oryzae strains and confocal laser scanning microscopy. Briefly, detached leaves of 30- to 40day-old plants of rice cv. Taichung Native-1 (TN-1) were inoculated with either wild-type or mutant $X$. oryzae pv. oryzae strains harboring the EGFP-expressing plasmid pMP2464. Inoculations were performed by dipping the leaves in bacterial culture for $1 \mathrm{~h}$ (described below). After $1 \mathrm{~h}$, the leaves were vortexed in sterile water (to get rid of loosely adhering bacteria) and examined in a confocal microscope. Beginning at the extreme tip of the leaf, optical sections parallel to the leaf surface were taken to detect EGFP fluorescence in three successive regions (each 200 by 200 by $90 \mu \mathrm{m}^{3}$ along the $\mathrm{X}, \mathrm{Y}$, and $\mathrm{Z}$ axis). For each strain, the total count of EGFP spots from this portion of the leaf was considered to be representative of the total number of cells of this strain that were associated with the leaf. Out of the total number of bacterial cells that were found to be in association with the leaf, a subpopulation was considered to be inside the leaves based on either one of two independent criteria. First, those bacterial cells which were found to be colocalizing with red autofluorescence of leaf (Fig. 1A) were considered to be inside the leaves. The second criterion was applied on the basis of colocalization of the EGFP signal with hydathodes. The hydathodal pores were clearly evident in the transmission or bright field images (not shown) and appeared as 'dark' (absence of any emission signal) areas when emission was observed in the red region $(650$ to $710 \mathrm{~nm}$ ) (Fig. 1B). Those cells were considered to be inside the hydathodal pores when EGFP signals were found to be colocalizing with such dark regions. These criteria were used to categorize colonized cells of $X$. oryzae pv. oryzae into two groups: one group of cells that was considered to be on the leaf surface and a second group that was considered to be 'inside' the leaf. The data presented in Figure 1 indicate that EGFPtagged wild-type $X$. oryzae pv. oryzae (BXO2141) cells were detected on the rice leaf surface as well as inside the leaves within $1 \mathrm{~h}$ of inoculation.

We then compared the efficiency with which BXO2141 colonized dorsal and ventral surfaces of rice leaves. An imaginary line, perpendicular to the leaf axis, was drawn at a point approximately $600 \mu \mathrm{m}$ from the leaf tip along the leaf axis. The entire leaf area between this line and the leaf tip was scanned up to a distance of $60 \mu \mathrm{m}$ from the dorsal as well as the ventral surfaces. A comparison of the total number of bacterial cells colonized over the dorsal and ventral surface (in this region of the leaf) suggests that $X$. oryzae pv. oryzae colonization was approximately twofold higher on the dorsal surface (Fig. 2). The pattern of $X$. oryzae pv. oryzae colonization of the dorsal surface of leaves was analyzed further. We scanned a region of the leaf extending up to the first $2 \mathrm{~cm}$ from the tip, along the leaf axis. An imaginary line, perpendicular to the leaf axis, was drawn at a point $2 \mathrm{~cm}$ from the leaf tip along the leaf axis. The entire leaf area between this line and the leaf tip was categorized into three blocks: the region present in the first $1 \mathrm{~mm}$ (along the leaf axis) from the leaf tip (block A), the region present between the first $1 \mathrm{~mm}$ to $1 \mathrm{~cm}$ from the leaf tip (block $\mathrm{B})$, and the region present between 1 and $2 \mathrm{~cm}$ from the leaf 
tip (block C). Confocal scanning of three randomly selected regions (each 200 by 200 by $60 \mu \mathrm{m}^{3}$ in the $\mathrm{X}, \mathrm{Y}$, and $\mathrm{Z}$ axis) from each block (designated as above) of BXO2141-infected leaves was performed and numbers of $X$. oryzae pv. oryzae cells colonized on the leaves were determined (Fig. 3). The results indicate that efficiency of leaf colonization by $X$. oryzae pv. oryzae in terms of number of bacterial cells per unit area was the highest toward the tip region (first $1 \mathrm{~mm}$ ) among the observed blocks.

A further analysis of leaf attachment or entry in the first-1$\mathrm{mm}$ region of the dorsal surface of the leaves was carried out. This region was divided into five different segments (segment I to V), with each segment corresponding to approximately $200 \mu \mathrm{m}$ in length along the leaf axis, beginning from the leaf tip. The number of $X$. oryzae pv. oryzae cells attached on the leaf surface as well as those inside the leaf in each segment (up to a depth of $90 \mu \mathrm{m}$ from the dorsal surface) was calculated. Approximately similar numbers of cells were present in each of the five segments, with possibly a greater number of cells present in segment III (Supplementary Fig. 1). However, the surface area of the leaf present in either segment IV or V was found to be at least twice that of the area of each of the first three segments (segment I, II, and III) as the leaf tapers toward the tip (data not shown). There-
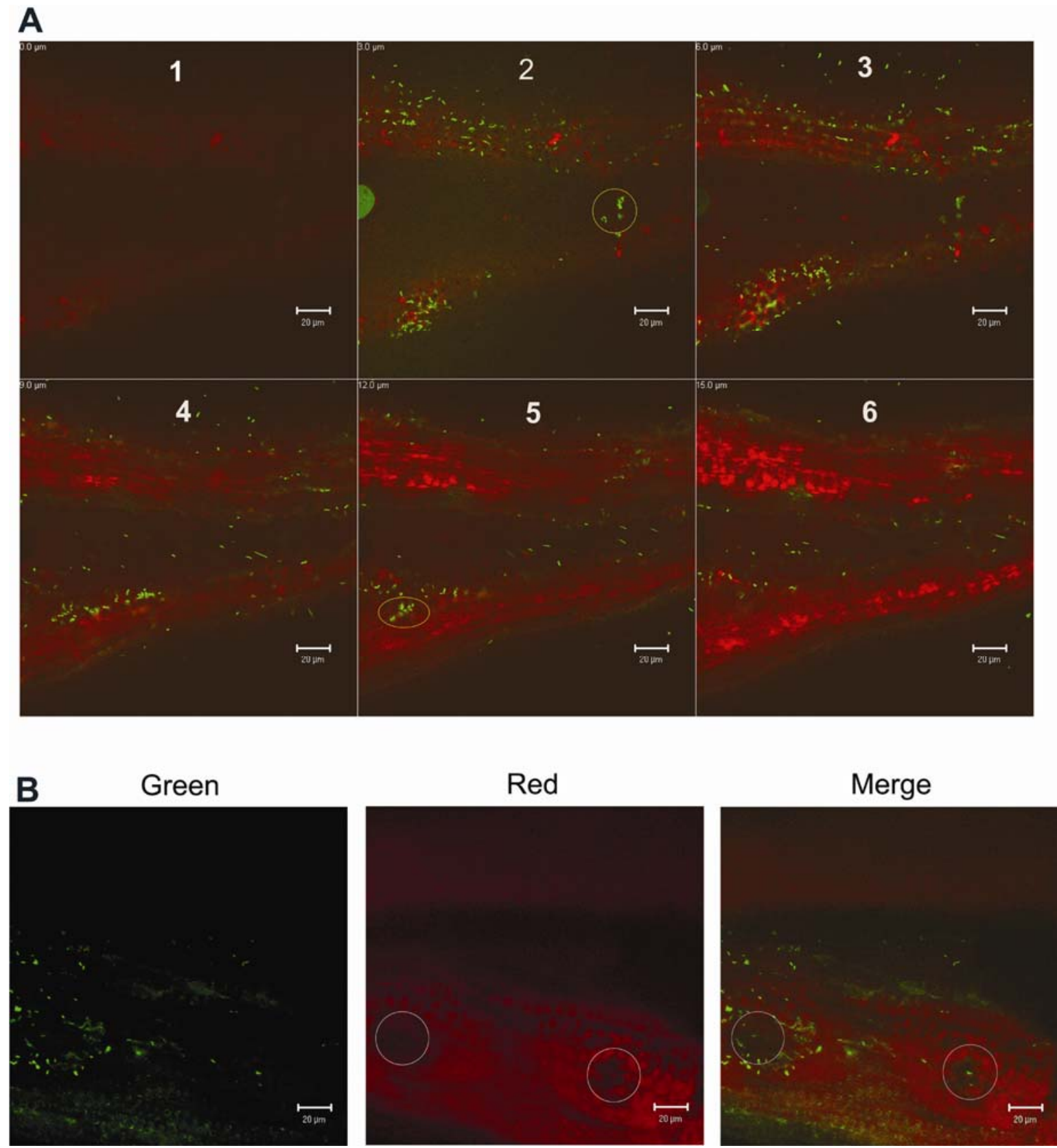

Fig. 1. A, Confocal microscope based matrix images of a rice leaf inoculated with enhanced green fluorescent protein (EGFP) expressing wild type Xanthomonas oryzae pv. oryzae (BXO2141). Excitation maximum was at $488 \mathrm{~nm}$ (argon laser) and emissions were collected at 510 to $530 \mathrm{~nm}$ (for EGFP fluorescence) and 650 to $710 \mathrm{~nm}$ (for leaf red autofluorescence). Sections 1 to 6 indicate successive optical sections of 3- $\mu \mathrm{m}$ thickness beginning from the dorsal surface of the leaf. An X. oryzae pv. oryzae cell was considered to be inside the leaf when the EGFP signal was found to colocalize with leaf red autofluorescence in the same X, Y, and Z axis. X. oryzae pv. oryzae cells indicated inside a circle (section 2) are considered to be on the surface whereas those inside the elliptical region (section 5) are considered to be inside the leaf. Scale bar: $20 \mu \mathrm{m}$. B, Confocal microscope-based projection image of a rice leaf (dorsal surface) inoculated with BXO2141. Encircled regions are indicative of hydathodal pores. X. oryzae pv. oryzae cells associated with such regions were also considered to be inside the leaf. Scale bar: $20 \mu \mathrm{m}$. 
fore, the number of bacteria per equivalent area in segments I, II, and III must be at least twice the number of bacteria per equivalent area in segments IV and V. Leaf sections were also taken in the Z-axis (beginning from the dorsal surface) and it was found that the EGFP signals were localized in a region extending up to approximately $90 \mu \mathrm{m}$ in depth (a representative example is shown in Supplementary Fig. 2). This indicates that maximal bacterial penetration occurs up to this depth within $1 \mathrm{~h}$ of infection.

\section{Mutations in $x a d A$ and $x a d B$ genes of $X$. oryzae pv. oryzae reduce the efficiency of rice leaf attachment and entry.}

The role of XadA in leaf attachment and entry was determined by examining the effect of two different xadA mutations (xadA2::Tn5gusA40 and xadA1::Tn5gusA40) on leaf attachment and entry. The data (Figs. 4 and 5) (Supplementary Table 1, experiments 1 to 3 ) show that a $x_{a d A^{-}}$mutant, BXO2181 (xadA2::Tn5gusA40), exhibits approximately 50\% deficiency in both leaf attachment and entry compared with the wild-type $X$. oryzae pv. oryzae strain $(\mathrm{BXO} 2141)$ and the cognate $\mathrm{xadA}^{+}$ revertant strain BXO2185 (Ray et al. 2002). Similar results were obtained with another $x a d A^{-}$mutant (xadA1::Tn5gusA40; BXO2191) which also exhibited an approximately $50 \%$ reduction in leaf attachment and entry compared with that of BXO2195 (the cognate $x a d A^{+}$revertant strain) (Ray et al. 2002) and the wild-type strain BXO2141. An insertion mutation in a truncated protease gene, prt1::Tn5Tet insertion (Ray et al. 2002), that is immediately downstream of $x a d A$ does not in any way affect leaf attachment or entry as determined by confocal microscopy (data not shown). This indicates that the deficiency in leaf attachment or entry that is associated with the $x a d A$ mutation is not due to a polar effect on transcription of the truncated protease gene.

$\mathrm{BXO} 2125, \mathrm{n} x a d B^{-}$mutant, was also found to be deficient in leaf attachment and entry compared with BXO2141, the wildtype $X$. oryzae pv. oryzae strain (Figs. 6 and 7) (Supplementary Table 2 ). The reduction in leaf attachment and entry was approximately 30 to $40 \%$ for BXO2125 compared with BXO2141. Most interestingly, BXO2155, a $x a d A^{-} x a d B^{-}$double mutant, was found to exhibit reduced efficiency for leaf attachment or entry compared with either of the single mutants, $\mathrm{BXO} 2181\left(x_{a d A^{-}}\right)$or BXO2125 $\left(x_{a d B}\right)$. The reduction in leaf attachment and entry was approximately 70 to $80 \%$ for BXO2155 compared with that of BXO2141.

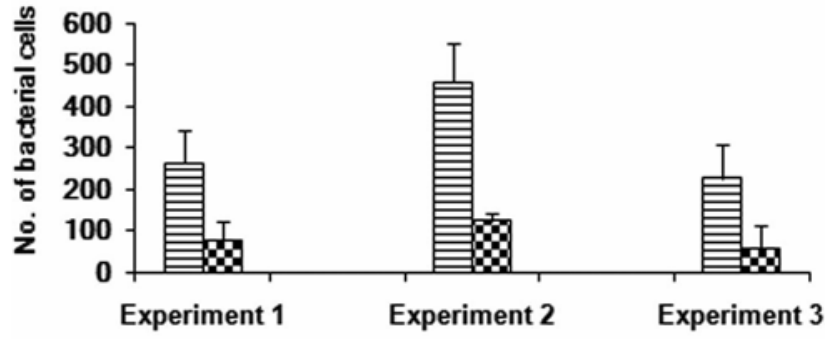

\section{日Dorsalsurface QVentral surface}

Fig. 2. Preferential colonization of the dorsal surface of rice leaves by Xanthomonas oryzae pv. oryzae. Rice leaves were inoculated with an enhanced green fluorescent protein-tagged wild-type $X$. oryzae pv. oryzae strain (BXO2141) and confocal microscopy assays were conducted $1 \mathrm{~h}$ after inoculation. The total number of bacterial cells present in an area of either the dorsal or ventral leaf surface extending from the leaf tip up to a distance of $600 \mu \mathrm{m}$ in length along the leaf axis and up to a maximum depth of $60 \mu \mathrm{m}$ from either the dorsal surface or the ventral surface was counted. In each experiment, at least three leaves were used and the data are presented as mean \pm standard deviation.
Effect of mutations in yapH and pilQ genes of $X$. oryzae pv. oryzae on rice leaf attachment and entry.

The role of the YapH protein of $X$. oryzae pv. oryzae in leaf attachment and entry was determined by examining the effect of a yapH mutation on leaf attachment and entry. The results indicate that a $\mathrm{yapH}^{-}$mutant $(\mathrm{BXO} 2115)$ exhibited a 20 to $25 \%$ reduction in leaf attachment or entry compared with the wild-type strain (BXO2141) (Fig. 8) (Supplementary Table 3). A $x a d A^{-}$mutant (BXO2181) was found to exhibit a greater deficiency in leaf attachment or entry in the same set of experiments compared with the yapH $H^{-}$mutant (BXO2115). To understand the role of type IV pilus in leaf attachment or entry by $X$. oryzae pv. oryzae, the efficiency of leaf attachment and entry of a pilQ $Q^{-}$mutant (BXO2105) was compared with that of the wild-type strain (BXO2141). It was found that there was no statistically significant difference in the number of BXO2105 cells present either on the leaf surface or inside the leaf compared with that of BXO2141 (Fig. 8).

\section{Infection efficiency of $\mathrm{xadB}^{-}, \mathrm{yapH}^{-}$, and pilQ $Q^{-}$mutants of $X$. oryzae pv. oryzae \\ following surface inoculation of rice leaves.}

The effect of mutations in adhesin-like functions of $X$. oryzae pv. oryzae on infection efficiency following surface inoculation was investigated. Leaves of 30- to 40-day-old rice plants (cv. $\mathrm{TN}-1$ ) were inoculated by dipping the leaves in bacterial cells that were resuspended in water (approximately $3 \times 10^{9}$ cells $/ \mathrm{ml}$ ). Infection efficiency was scored by determining the percentage of infected leaves showing disease lesions 21 days after inoculation. The results of four independent experiments are presented in Table 1 . As previously shown (Ray et al. 2002), a $x a d A^{-}$mutant (BXO837) exhibited a reduction in epiphytic infection efficiency compared with the wild-type strain (BXO43). The data also indicate that, in three of four experiments, the $x a d B^{-}$mutant (BXO2121) exhibited reduced infection efficiency compared with BXO43. A $x a d A^{-} x a d B^{-}$double mutant (BXO2151) exhibited a reduction in infection efficiency compared with the $x a d B^{-}$ (BXO2121) mutant in all four experiments and a reduction in infection efficiency in only one of four experiments compared with the $x a d A^{-}$mutant. A yapH $H^{-}$mutant (BXO2111) exhibited reduced infection efficiency compared with BXO43 in two of four experiments. BXO2101, a pilQ $Q^{-}$mutant, exhibited reduced infection efficiency compared with that of BXO43 in two of four experiments.

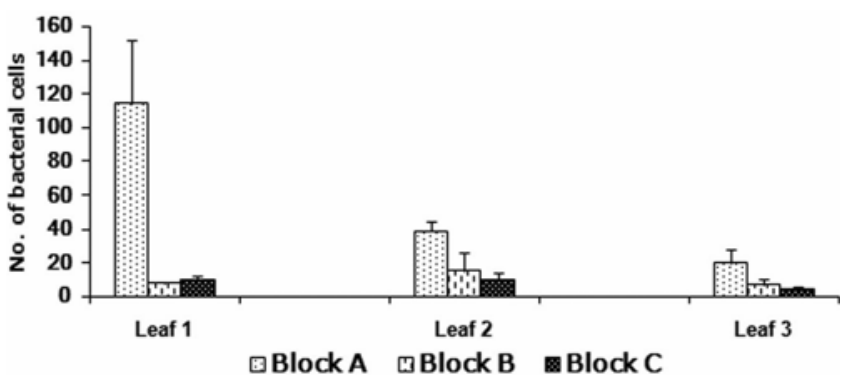

Fig. 3. Preferential colonization of the tip region of rice leaves by Xanthomonas oryzae pv. oryzae. Rice leaves were inoculated with an enhanced green fluorescent protein-tagged wild-type $X$. oryzae pv. oryzae strain (BXO2141) and confocal microscopic assays were conducted $1 \mathrm{~h}$ after inoculation. Confocal scanning was performed in three designated blocks of rice leaves: Block A, first $1 \mathrm{~mm}$ from leaf tip along the leaf axis; Block $\mathrm{B}, 1 \mathrm{~mm}$ to $1 \mathrm{~cm}$; and Block $\mathrm{C}, 1$ to $2 \mathrm{~cm}$. In each block, three randomly selected regions of 200 by 200 by $60 \mu \mathrm{m}^{3}$ in the $\mathrm{X}, \mathrm{Y}$, and $\mathrm{Z}$ axis beginning from the dorsal surface were scanned and the total number of bacterial cells in each such region was counted. The mean and standard deviation of bacterial cells in a 200-by-200-by-60- $\mu \mathrm{m}^{3}$ region of each block of the leaf was then determined. 
Virulence phenotypes of $\mathrm{xadB}^{-}, \mathrm{yapH}^{-}$, and pilQ $Q^{-}$mutants of $X$. oryzae pv. oryzae

following wound inoculation of rice leaves.

The effect of mutations in adhesin-like functions of $X$. oryzae pv. oryzae on virulence was also assessed by wound inoculation. Leaves of 30- to 40-day-old rice plants (TN-1) were clip inoculated by scissors dipped in bacterial suspensions. Lesion lengths were measured 7 days after inoculation. Results of four independent experiments are presented in Table 2. The average lesion lengths caused by BXO837 $\left(\mathrm{xadA}^{-}\right)$, BXO2121 $\left(x a d B^{-}\right)$, and BXO2151 (xadA- $\left.x a d B\right)$ were not statistically different compared with that of BXO43 (the wild type). Similar results were obtained when lesion lengths were recorded for these strains either 10 or 14 days after inoculation (data not shown). Interestingly, BXO2111, a yapH ${ }^{-}$, mutant exhibited a moderate deficiency in lesion length compared with
BXO43 while $\mathrm{BXO} 2101$, a pilQ $Q^{-}$mutant, showed a greater reduction in lesion length compared with BXO43. Similar results were obtained when lesion lengths were recorded for these strains either 10 or 14 days after inoculation (data not shown).

The effect of mutations in genes for adhesin-like functions on in planta migration or growth of $X$. oryzae pv. oryzae was also determined following wound inoculation. The results of three independent experiments indicate that the distances migrated in the leaf 4 days after inoculation by BXO837 $\left(\mathrm{xadA}^{-}\right)$ and BXO2121 $\left(\mathrm{xadB}^{-}\right)$were very similar to that of BXO43 (the wild type) whereas the distances migrated by BXO2111 $\left(\right.$ yapH $\left.^{-}\right)$and $\mathrm{BXO} 2101$ (pilQ $\left.Q^{-}\right)$were significantly reduced compared with BXO43 (Table 3). In independent experiments, the distance migrated by the $x a d A^{-} x a d B^{-}$double mutant (BXO2151) was found to be similar to that of BXO43 (data not shown).

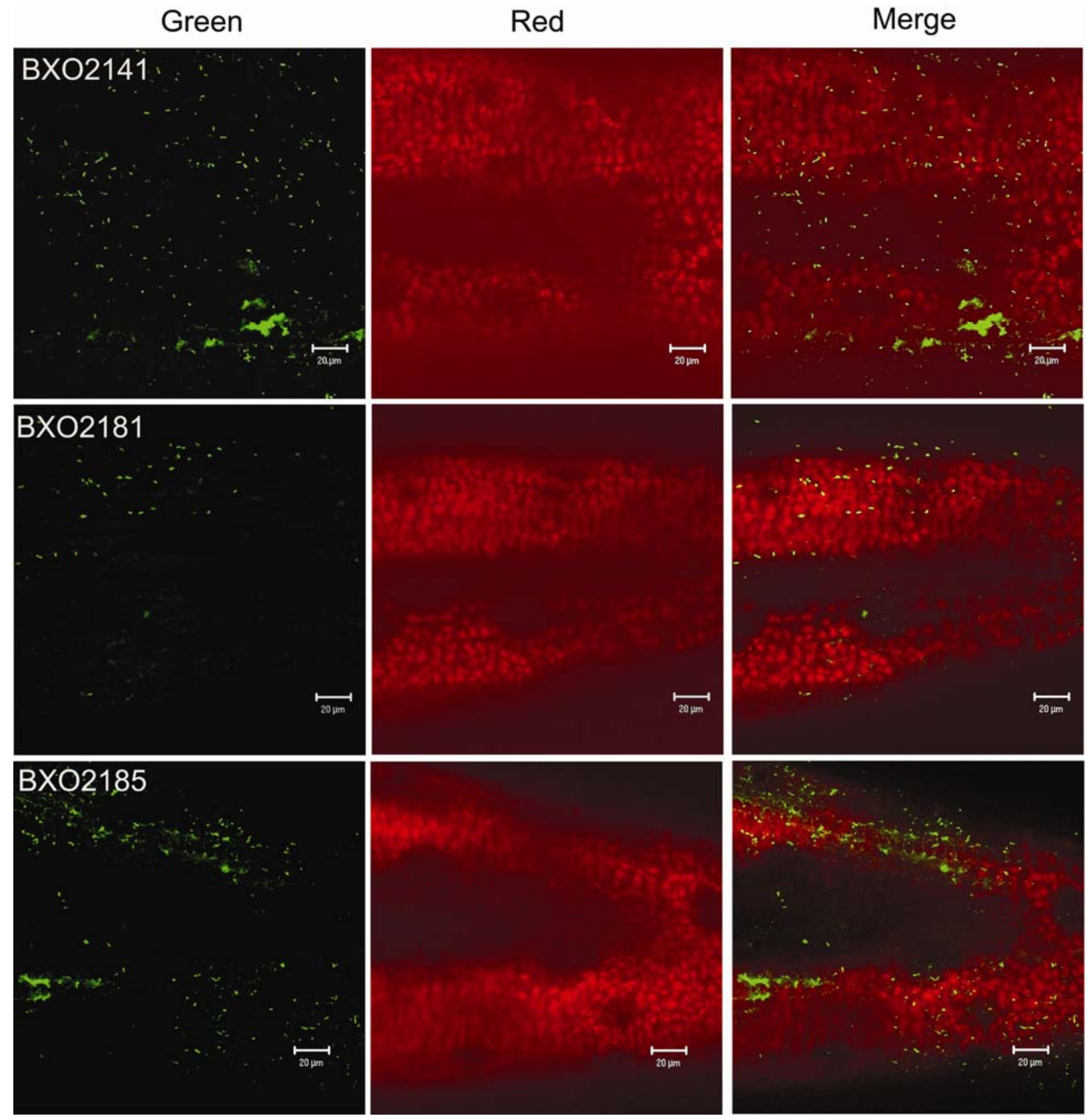

Fig. 4. $x a d A^{-}$mutant of Xanthomonas oryzae pv. oryzae exhibits a deficiency in leaf attachment and entry. Rice leaves were inoculated with enhanced green fluorescent protein-tagged $X$. oryzae pv. oryzae strains and confocal microscopy-based assays were conducted $1 \mathrm{~h}$ after inoculation. The figure depicts confocal microscope based projection images ( 200 by 200 by $60 \mu \mathrm{m}^{3}$ in the $\mathrm{X}, \mathrm{Y}$, and Z axis beginning from the dorsal surface) of rice leaves inoculated with BXO2141 (wild type); BXO2181 (xadA2::mTn5gusA40), and BXO2185 (xadA ${ }^{+}$revertant). Scale bar: $20 \mu \mathrm{m}$. 
Effect of mutations in genes for adhesin-like functions of $X$. oryzae pv. oryzae on adhesion to glass surface.

The affinity for adhesion of $X$. oryzae pv. oryzae cells to a biologically inert substratum such as a glass surface and the role of XadA, XadB, YapH, and PilQ proteins in attachment of $X$. oryzae pv. oryzae to the same was investigated. The following strains were used: BXO43 (wild type), BXO837 $\left(\right.$ xadA $\left.^{-}\right)$, BXO2121 $\left(x a d B^{-}\right), \mathrm{BXO} 2111\left(y_{a p H^{-}}\right), \mathrm{BXO} 2101\left(\right.$ pil $\left.^{-}\right)$, and

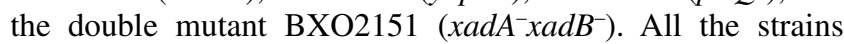
were grown in peptone-sucrose (PS) medium up to early stationary phase, pelleted down, washed, and resuspended in sterile water (approximately $1 \times 10^{9}$ cells $/ \mathrm{ml}$ ). These suspensions were then used to make a bacterial smear on glass slides and incubated at $28^{\circ} \mathrm{C}$. After $1 \mathrm{~h}$ of incubation, the slides were rinsed in sterile water, air dried, and observed in an atomic force microscope (AFM). In all the strains, clusters of bacterial cells as well as singly adhered cells were observed (data not shown). There was no difference in colony types, cell numbers, and morphology among all the strains observed. All of the strains formed large bacterial clusters, often multilayered, and also appeared to form biofilm-like structures.

\section{DISCUSSION}

The genome sequences of pathogenic bacteria indicate that multiple adhesin-like functions are encoded in their genomes. In part, this may be because it helps to have functional redundancy in terms of attachment to any particular host surface and also because the pathogen requires multiple adhesins at different stages of the infection process. Using an in silico approach, we have identified several adhesin-like functions in the genome of X. oryzae pv. oryzae (Lee et al. 2005; Ochiai et al. 2005; Salzberg et al. 2008). These are the previously described $\mathrm{XadA}$; a paralog of XadA called XadB; a protein that is homologous to the Yersinia virulence factor $\mathrm{YapH}$, which is predicted to encode an autransporter adhesin; and a type IV pilus. The PXO99A strain of $X$. oryzae pv. oryzae has a strain-specific gene cluster which encodes several filamentous hemagluttininlike functions that might function in adhesion; however, the role of this gene cluster in virulence is unclear because it is

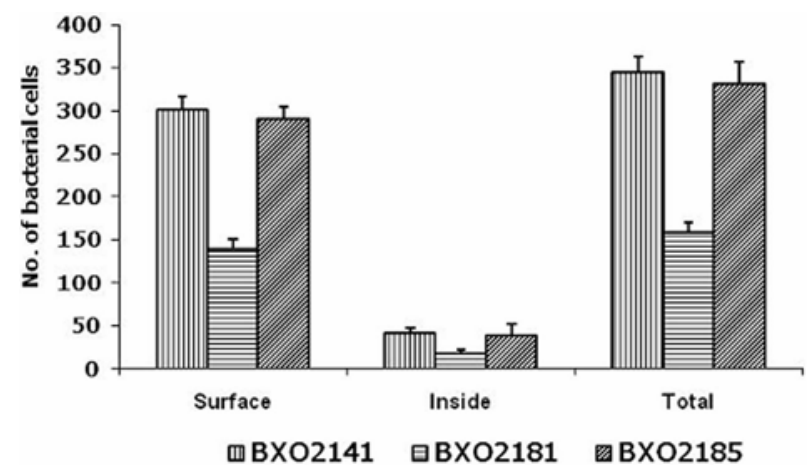

Fig. 5. Reduction in leaf attachment and entry is associated with $x a d A^{-}$ mutation of Xanthomonas oryzae pv. oryzae. The number of enhanced green fluorescent protein-expressing cells of $X$. oryzae pv. oryzae wild type (BXO2141), xadA ${ }^{-}$mutant (BXO2181, xadA2::Tn5 gusA40), and $x a d A^{+}$recombinant strain $(\mathrm{BXO} 2185$, derived from xadA2::Tn5 gusA40 mutant) on the surface as well as inside rice leaves after $1 \mathrm{~h}$ of infection was determined using confocal microscopy. Data were collected up to approximately $600 \mu \mathrm{m}$ in length from the tip of the leaf and a distance of approximately $90 \mu \mathrm{m}$ in depth from the dorsal surface of each leaf. Each bar shows a mean and standard deviation of values obtained from three leaves. The values obtained for the $x a d A^{-}$mutant were found to be significantly different $(P<0.05)$ compared with either the wild-type strain or the $x a d A^{+}$recombinant in a student's two-tailed $t$ test for independent means. Similar results were obtained in independent experiments. absent from the $X$. oryzae pv. oryzae strains KACC10331 and MAFF311018 as well as the BXO43 strain that has been used in this study (Salzberg et al. 2008).

XadA has been already reported to promote infection following surface inoculation of rice leaves (Ray et al. 2002). A reverse genetics approach was adopted to understand the role of the other adhesin-like functions of $X$. oryzae pv. oryzae in leaf attachment and entry as well as virulence. Mutations were generated in the selected genes ( $x a d B, y a p H$, and pilQ) by integration of recombinant plasmid (pK18mob) by homologous recombination. The genomic organization of $x a d B, y a p H$, and pilQ in $X$. oryzae pv. oryzae shows that the downstream genes of both yapH and pilQ are in opposite transcriptional orientation and it is unlikely that the phenotypes associated with mutation of these genes is due to a polar effect on any downstream transcripts. The gene immediately downstream of $x a d B$ is a protease gene, which is in the same transcriptional orientation, and there is a possibility that it might be co-transcribed with $x a d B$. However, the mutation in the $x a d B$ gene was isolated in such a manner that the lac promoter of $\mathrm{pK} 18 \mathrm{mob}$ can drive transcription of genes that might be co-transcribed with $x a d B$. A similar methodology was adopted earlier to generate nonpolar mutations in $X$. campestris pv. campestris and $P$. aeruginosa (Wei et al. 2007; Windgassen et al. 2000).

In this study, we have developed an assay to monitor early stages of rice leaf attachment and entry by $X$. oryzae pv. oryzae using EGFP as a reporter. The plasmid pMP2464, which expresses EGFP constitutively under lacZ promoter, was mobilized to wild-type $X$. oryzae pv. oryzae as well as the strains that are mutants for adhesin-like functions. After $1 \mathrm{~h}$ of inoculation with EGFP-tagged strains of $X$. oryzae pv. oryzae, the leaves were vortexed briefly in water to get rid of the loosely adhered bacterial cells. The leaves were scanned in a confocal microscope using an excitation maximum of $488 \mathrm{~nm}$ and emissions were collected in two different regions of the spectrum, 510 to 530 and 650 to $710 \mathrm{~nm}$, for the detection of EGFP fluorescence and leaf red autofluorescence, respectively. Occasionally, leaf green autofluorescence was detected in the 510to-530-nm region. We differentiated leaf green autofluorescence and EGFP fluorescence using morphological criteria as well as emission fingerprinting (described below). Bacteria were considered to have entered rice leaves if they either showed colocalization with leaf red autofluorescence in the same optical section or were found to be associated with hydathodes.

The results suggest that $X$. oryzae pv. oryzae cells can enter into rice leaves within the first $1 \mathrm{~h}$ after infection. These results are consistent with an earlier study (Hugouvieux et al. 1998), wherein it was shown that $X$. campestris pv. campestris enters into Arabidopsis thaliana leaves within $1 \mathrm{~h}$ of infection. Our results also suggest that colonization and leaf entry occur preferentially via the dorsal surface and that there is greater bacterial colonization of the first $1 \mathrm{~mm}$ of the leaf (from the leaf tip along the leaf axis) compared with the region of the leaf that is present between either $1 \mathrm{~mm}$ and $1 \mathrm{~cm}$ or 1 and $2 \mathrm{~cm}$. These results are consistent with earlier observations that hydathodes are preferentially localized to the dorsal surface and to the tip regions of rice leaves (Mew et al. 1984). Within the first-1-mm region, there is a greater density of bacterial colonization within the first $600 \mu \mathrm{m}$ from the leaf tip.

A comparison of the efficiency of leaf attachment or entry by wild-type and mutant strains of $X$. oryzae pv. oryzae was made by examining the number of bacterial cells on the dorsal surface in a region along the leaf surface within the first $600 \mu \mathrm{m}$ in length from the leaf tip as well as within the leaf to a depth of 90 $\mu \mathrm{m}$, beginning from the dorsal surface. This was considered to be representative of the efficiency of leaf attachment or entry for each strain. Our results indicate that, compared with $x_{a d A}$ 
strains, two different $x a d A^{-}$mutants (BXO2181 and BXO2191) exhibited a deficiency in leaf attachment and entry. A $x a d B^{-}$mutant (BXO2125) also exhibited a deficiency in leaf attachment or entry, although it was less severe than the deficiency associated with mutations in the $x a d A$ gene. A $x a d A^{-} x a d B^{-}$double mutant (BXO2155) exhibited an even greater deficiency in leaf attachment and entry compared with either the $x a d A^{-}$or $x a d B^{-}$single mutants. This additive effect indicates that both genes are independently contributing to leaf attachment and entry.
Ray and associates (2002) had earlier shown that $x a d A^{-}$mutants are defective in the ability to cause disease following surface inoculation of rice leaves. The results obtained in this study were consistent with these findings. Under the same conditions, an $x a d B^{-}$mutant (BXO2121) exhibited an infection deficiency in three of four experiments. The $x a d A^{-} x a d B^{-}$double mutant exhibited a greater infection deficiency than the $x a d B^{-}$single mutant in all four experiments whereas it exhibited a greater infection deficiency than the $x a d A^{-}$mutant in only one of four
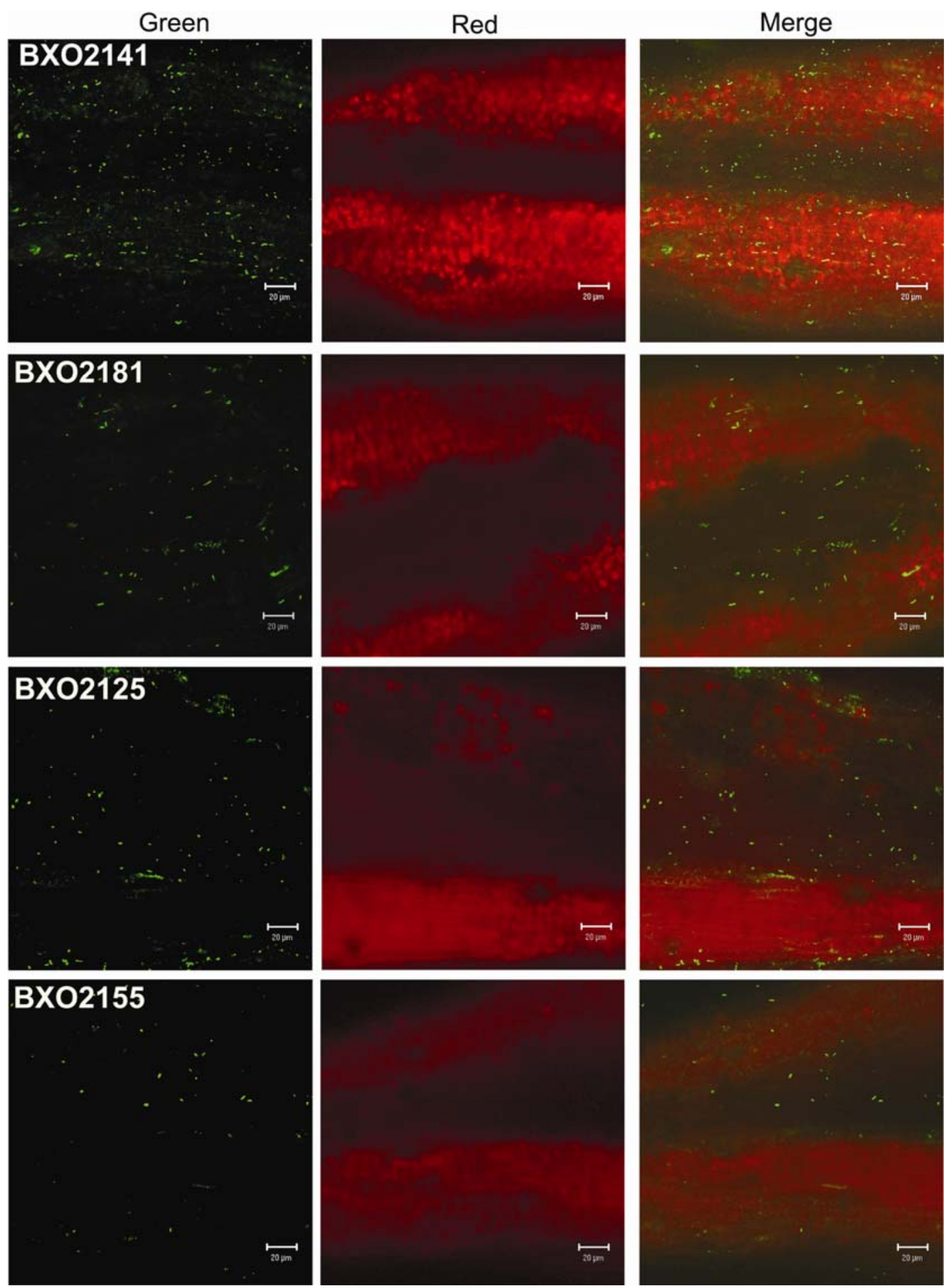

Fig. 6. $x a d B$ mutation of Xanthomonas oryzae pv. oryzae causes deficiency in leaf attachment and entry into rice. Inoculations of rice leaves with enhanced green fluorescent protein-tagged $X$. oryzae pv. oryzae strains were done and confocal microscopy based assays were conducted $1 \mathrm{~h}$ after inoculation. The panels depict confocal microscope based projection images ( 200 by 200 by $60 \mu \mathrm{m}^{3}$ in the $\mathrm{X}, \mathrm{Y}$, and $\mathrm{Z}$ axis beginning from the dorsal surface) of rice leaves

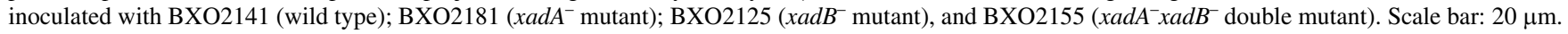




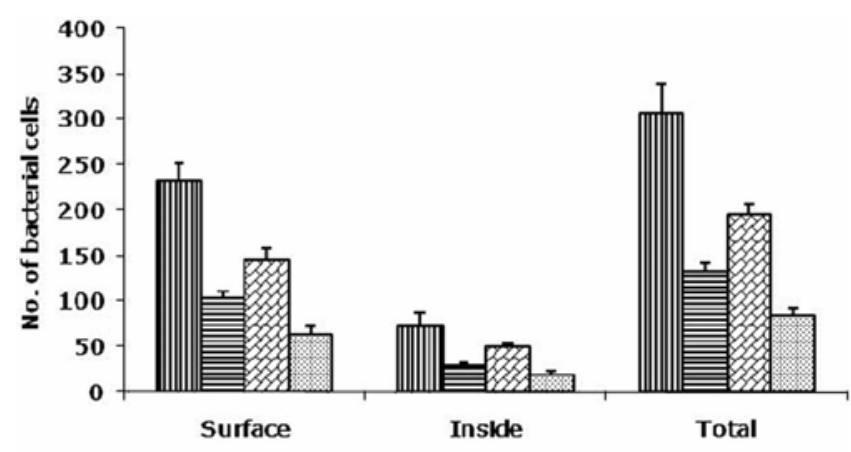

mBX02141 घBX02181 घBХ02125 ๓BХ02155

Fig. 7. Reduction in leaf attachment and entry is associated with an $x a d B$ mutation of Xanthomonas oryzae pv. oryzae. The number of enhanced green fluorescent protein-expressing cells of $X$. oryzae pv. oryzae wild type (BXO2141), xadA $A^{-}$mutant (BXO2181), $x a d B^{-}$mutant (BXO2125), and $x a d A^{-} x a d B^{-}$double mutant (BXO2155) on the surface as well as inside rice leaves after $1 \mathrm{~h}$ of infection was determined using confocal microscopy. Data were collected up to approximately $600 \mu \mathrm{m}$ in length from the tip of the leaf and a distance of approximately $90 \mu \mathrm{m}$ in depth from the dorsal surface of each leaf. Each bar shows a mean and standard deviation of values obtained from three leaves. A student's two-tailed $t$ test for independent means was performed in pairwise combinations between the wild type and all mutants as well as between the double mutant and both the single mutants. The differences were found to be significant $(P<$ 0.05 ) in all of these comparisons. Similar results were obtained in independent experiments.

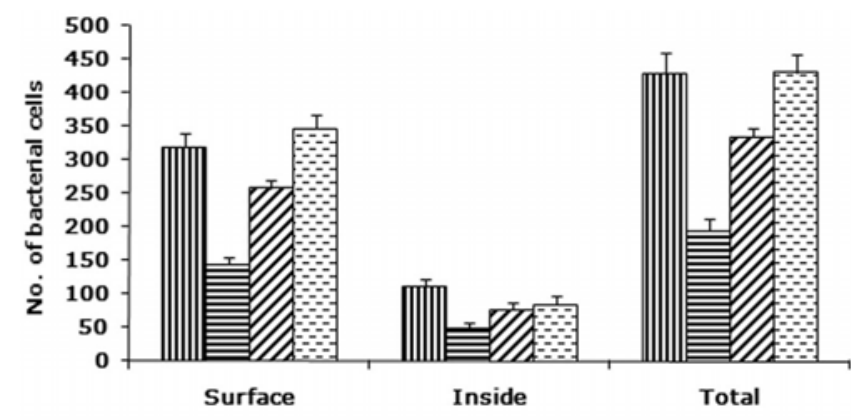

mBX02141 घBX02181 घBX02115 ๘BX02105

Fig. 8. Effect of mutations in yapH and pilQ genes of Xanthomonas oryzae pv. oryzae on leaf attachment and entry. The numbers of enhanced green fluorescent protein-expressing cells of $X$. oryzae pv. oryzae wild

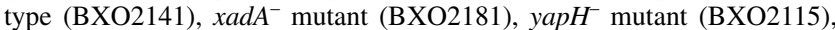
and pilQ $Q^{-}$mutant (BXO2105) on the surface as well as inside rice leaves after $1 \mathrm{~h}$ of infection were determined using confocal microscopy. Data were collected up to approximately $600 \mu \mathrm{m}$ in length from the tip of the leaf and a distance of approximately $90 \mu \mathrm{m}$ in depth from the dorsal surface of each leaf. Each bar shows a mean and standard deviation of values obtained from three leaves. A student's two-tailed $t$ test for independent means was performed in pairwise combinations between the wild type and all mutants. The difference between the wild type (BXO2141) and either $\mathrm{xadA}^{-}$(BXO2181) or $\mathrm{yapH}^{-}$(BXO2115) mutant was found to be significant but the difference between the wild type and pilQ $Q^{-}$mutant (BXO2105) $(P<0.05)$ was not found to be significant. Similar results were obtained in independent experiments.

Table 1. Effect of mutations in genes for adhesin-like functions of Xanthomonas oryzae pv. oryzae on efficiency of infection following surface inoculation

\begin{tabular}{|c|c|c|c|c|c|c|}
\hline \multirow[b]{2}{*}{ Experiment } & \multicolumn{6}{|c|}{ Efficiency of infection $(\%)^{\mathrm{z}}$} \\
\hline & BXO43 (wild type) & BXO837 $\left(\mathrm{xadA}^{-}\right)$ & BXO2121 (xadB $\left.)^{-}\right)$ & BXO2151 (xadA xadB $\left.^{-}\right)$ & BXO2111 (yapH-) & BXO2101 (pilQ $\left.{ }^{-}\right)$ \\
\hline No. 1 & 59 a (7/12) & $31(4 / 13)$ & $50 \mathrm{a}(6 / 12)$ & $17(2 / 12)$ & $46(6 / 13)$ & $31(4 / 13)$ \\
\hline No. 2 & 60 a (6/10) & $40 \mathrm{~b}(4 / 10)$ & $46(5 / 11)$ & $34 \mathrm{~b}(6 / 18)$ & 50 a (6/12) & $25(3 / 12)$ \\
\hline No. 3 & 53 a $(10 / 19)$ & $27 \mathrm{~b}(4 / 15)$ & $39(5 / 13)$ & $22 \mathrm{~b}(4 / 18)$ & $40(4 / 10)$ & 60 a (6/10) \\
\hline No. 4 & $42 \mathrm{a}, \mathrm{b}(5 / 12)$ & 20 c (3/15) & $23(4 / 18)$ & 12 c (2/17) & $45 \mathrm{a}(8 / 18)$ & 44 b (7/16) \\
\hline
\end{tabular}

${ }^{\mathrm{z}}$ Percent efficiency of infection is presented. Values in parentheses indicate the number of leaves that exhibited infection symptoms compared with the total number of infected leaves. The leaves of 30- to 40-day-old rice plants (Taichung Native-1) were inoculated and the symptoms were scored 21 days after inoculation. A $\chi^{2}$ goodness of fit analysis (two-tailed) at $P<0.05$ was performed between the wild type and each of the single mutants, keeping the value obtained for the wild-type strain as expected. A similar analysis was done between the $x a d A$ and $x a d A x a d B$ double mutant as well as between the $x a d B$ and $x a d A x a d B$ double mutant, wherein the value obtained for the single mutant was considered to be the expected value. Values marked with the same letter do not exhibit any significant deviation at $P<0.05$.

Table 2. Effect of mutations in genes for adhesin like functions on virulence of Xanthomonas oryzae pv. oryzae as assessed by wound inoculation

\begin{tabular}{|c|c|c|c|c|c|c|}
\hline \multirow[b]{2}{*}{ Experiment } & \multicolumn{6}{|c|}{ Lesion length $(\mathrm{cm})^{\mathrm{z}}$} \\
\hline & BXO43 (wild type) & BXO837 $\left(\mathrm{xadA}^{-}\right)$ & BXO2121 (xadB $\left.)^{-}\right)$ & BXO2151 (xadA-xadB $\left.{ }^{-}\right)$ & BXO2111 (yapH-) & BXO2101 (pilQ $\left.{ }^{-}\right)$ \\
\hline No. 1 & $4.5 \pm 0.4 \mathrm{~b}$ & $4.2 \pm 0.5 \mathrm{~b}$ & $4.3 \pm 0.8 \mathrm{~b}$ & $4.2 \pm 0.9 \mathrm{~b}$ & $3.3 \pm 0.2$ & $2.1 \pm 0.4$ \\
\hline No. 2 & $4.9 \pm 0.7 \mathrm{~b}$ & $4.8 \pm 0.7 \mathrm{~b}$ & $4.7 \pm 1.0 \mathrm{~b}$ & $4.7 \pm 0.6 \mathrm{~b}$ & $3.4 \pm 0.5$ & $2.9 \pm 0.6$ \\
\hline No. 3 & $5.6 \pm 0.5 b$ & $5.3 \pm 0.8 b$ & $5.4 \pm 0.7 b$ & $5.1 \pm 0.7 b$ & $4.0 \pm 0.6$ & $2.3 \pm 0.3$ \\
\hline No. 4 & $4.4 \pm 0.2 b$ & $4.1 \pm 0.9 \mathrm{~b}$ & $4.5 \pm 0.9 \mathrm{~b}$ & $4.2 \pm 0.9 \mathrm{~b}$ & $3.2 \pm 0.4$ & $2.7 \pm 0.7$ \\
\hline
\end{tabular}

${ }^{\mathrm{z}}$ Leaves of rice cv. Taichung Native-1 were wound inoculated with $X$. oryzae pv. oryzae strains and lesion lengths $(\mathrm{cm})$ were measured 7 days after inoculation. The lesion length was measured from at least 10 infected leaves/strain/experiment and the mean values were determined. A student's two-tailed $t$ test for independent means was performed in pairwise combinations for each of the mutants with the wild type (BXO43). Values with the same letter are not significantly different $(P<0.05)$ compared with the wild type.

Table 3. Effect of mutations in adhesin-like functions of Xanthomonas oryzae pv. oryzae on in planta migration

\begin{tabular}{|c|c|c|c|c|c|}
\hline \multirow[b]{2}{*}{ Experiment } & \multicolumn{5}{|c|}{ Average distance migrated within the leaf by $X$. oryzae pv. oryzae strains $(\mathrm{cm})^{\mathrm{z}}$} \\
\hline & BXO43 (wild type) & BXO837 $\left(\mathrm{xadA}^{-}\right)$ & BXO2121 (xadB $\left.{ }^{-}\right)$ & BXO2101 (pilQ-) & BXO2111 (yapH-) \\
\hline No. 1 & $4.5 \pm 0.1 \mathrm{~b}$ & $4.4 \pm 0.2 b$ & $4.3 \pm 0.2 b$ & $1.9 \pm 0.2$ & $3.2 \pm 0.2$ \\
\hline No. 2 & $3.5 \pm 0.3 \mathrm{~b}$ & $3.5 \pm 0.4 b$ & $3.4 \pm 0.4 \mathrm{~b}$ & $0.8 \pm 0.2$ & $1.8 \pm 0.5$ \\
\hline No. 3 & $3.2 \pm 0.1 \mathrm{~b}$ & $3.3 \pm 0.4 b$ & $3.0 \pm 0.6 \mathrm{~b}$ & $0.9 \pm 0.1$ & $2.0 \pm 0.2$ \\
\hline
\end{tabular}

${ }^{\mathrm{z}}$ Leaves of 30- to 40-day-old rice plants (cv. Taichung Native-1) were wound inoculated and the distance migrated was estimated as described in Materials and Methods. At least three leaves were inoculated with each bacterial strain per experiment. A student's two-tailed $t$ test for independent means was performed in pairwise combinations for each of the mutants with the wild type (BXO43). Values with the same letter are not significantly different $(P<$ 0.05 ) compared with the wild type. 
experiments. These data indicate that the XadA protein is more important than the XadB protein for the ability of the bacterium to cause disease following surface inoculation of rice leaves. However, neither the $x a d A^{-}$nor the $x a d B^{-}$single mutants or the $x a d A^{-} x a d B^{-}$double mutant exhibited a deficiency in virulence following wound inoculation. These data, in conjunction with the confocal analysis, indicates that the XadA and XadB proteins are primarily involved in promoting virulence following surface inoculation, possibly by functioning in colonization of leaf surfaces and entry into leaves through the hydathodes. Wound inoculation involves direct entry into the xylem vessels and it appears that the $\mathrm{XadA}$ and $\mathrm{XadB}$ proteins may have, at best, a minor role in promoting growth within xylem vessels. It is important to note that wound inoculation involves bypassing the primary natural mode of entry of $X$. oryzae pv. oryzae, which is through the hydathodes.
In the confocal microscopic assay, the $y a p H^{-}$mutant (BXO2115) exhibited a deficiency in leaf attachment and entry compared with the wild-type strain. However, the $y a p H^{-}$mutant is not as deficient at leaf attachment and entry as the $x a d A^{-}$mutant. Also, the apH $^{-}$mutant $(\mathrm{BXO} 2111)$ exhibited a reduction in infection efficiency following surface inoculation in two of four experiments. This again indicates that the $\mathrm{yapH}^{-}$mutant was not as deficient in infection following this mode of inoculation as the $x a d A^{-}$mutant. However, the $y a p H^{-}$mutant always exhibited a reduction in virulence compared with the wild-type strain following wound inoculation. Also, the $y a p H^{-}$mutant exhibited a deficiency for in planta migration. This indicates that the $\mathrm{YapH}$ protein has a role in promoting virulence of $X$. oryzae pv. oryzae when it is growing inside the xylem vessels. This is the first report about the role of a YapH-like protein in promoting virulence of any plant-pathogenic bacterium.

Table 4. List of bacterial strains, plasmids, and primers used in the present study

\begin{tabular}{|c|c|c|}
\hline $\begin{array}{l}\text { Bacterial strains, } \\
\text { plasmids, primers }^{y}\end{array}$ & Relevant characteristics $^{\mathrm{z}}$ & Reference, source \\
\hline \multicolumn{3}{|l|}{ Strains } \\
\hline \multicolumn{3}{|l|}{$X$. oryzae pv. oryzae } \\
\hline BXO43 & rif-2; $\mathrm{Rf}^{\mathrm{r}}$; laboratory wild-type strain & Laboratory collection \\
\hline BXO837 & xadA2::Tn5 gusA40 rif-2; derived from BXO43 & Ray et al. 2002 \\
\hline BXO847 & $z x x-110:: T n 10$ rif- $2 ; x a d A^{+}$recombinant obtained from BXO837 & Ray et al. 2002 \\
\hline BXO836 & xadA1::Tn5 gusA40 rif-2; derived from BXO43 & Ray et al. 2002 \\
\hline BXO846 & $z x x-110:: T n 10$ rif- $2 ; x a d A^{+}$recombinant obtained from BXO836 & Ray et al. 2002 \\
\hline BXO2101 & pilQ::pK18mob rif2; $\mathrm{Km}^{\mathrm{r}}$, derived from $\mathrm{BXO} 43$ & This work \\
\hline $\mathrm{BXO} 2111$ & yapH::pK18mob rif2; $\mathrm{Km}^{\mathrm{r}}$, derived from $\mathrm{BXO} 43$ & This work \\
\hline $\mathrm{BXO} 2121$ & $x a d B:: \mathrm{pK} 18 \mathrm{mob}$ rif2; derived from $\mathrm{BXO} 43$ & This work \\
\hline BXO2151 & $x a d A 2:: m T n 5$ xadB::pK18mob rif2; derived from BXO837 & This work \\
\hline BXO884 & prt1::Tn5Tet rif-2; derived from BXO43 & Ray et al. 2002 \\
\hline BXO2141 & $\mathrm{BXO} 43 / \mathrm{pMP} 2464 ; \mathrm{EGFP}^{+}, \mathrm{Gm}^{\mathrm{r}}$ & This work \\
\hline BXO2181 & $\mathrm{BXO} 837 / \mathrm{pMP} 2464 ; \mathrm{EGFP}^{+}, \mathrm{Gm}^{\mathrm{r}}$ & This work \\
\hline BXO2191 & 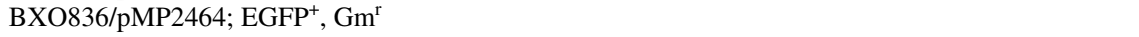 & This work \\
\hline BXO2195 & 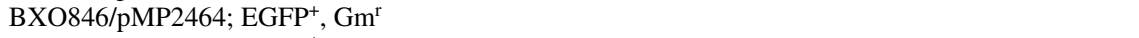 & This work \\
\hline $\mathrm{BXO} 2185$ & $\mathrm{BXO} 847 / \mathrm{pMP} 2464 ; \mathrm{EGFP}^{+}, \mathrm{Gm}^{\mathrm{r}}$ & This work \\
\hline $\mathrm{BXO} 2125$ & $\mathrm{BXO} 2121 / \mathrm{pMP} 2464 ; \mathrm{EGFP}^{+}, \mathrm{Gm}^{\mathrm{r}}$ & This work \\
\hline $\mathrm{BXO} 2105$ & $\mathrm{BXO} 2101 / \mathrm{pMP} 2464 ; \mathrm{EGFP}^{+}, \mathrm{Gm}^{\mathrm{r}}$ & This work \\
\hline $\mathrm{BXO} 2115$ & $\mathrm{BXO} 2111 / \mathrm{pMP} 2464 ; \mathrm{EGFP}^{+}, \mathrm{Gm}^{\mathrm{r}}$ & This work \\
\hline $\mathrm{BXO} 2155$ & $\mathrm{BXO} 2151 / \mathrm{pMP} 2464 ; \mathrm{EGFP}^{+}, \mathrm{Gm}^{\mathrm{r}}$ & This work \\
\hline BXO2190 & $\mathrm{BXO} 884 / \mathrm{pMP} 2464 ; \mathrm{Gm}^{\mathrm{R}}$ & This work \\
\hline \multicolumn{3}{|l|}{ E. coli } \\
\hline S17-1 & RP4-2-Tc::Mu-Km::Tn7 pro hsd recA & Simon et al.1983 \\
\hline DH5 $\alpha$ & $\mathrm{F}^{\prime}$, end $\mathrm{A} 1$ hsdR17 ( $\left.\mathrm{rk}^{-} \mathrm{mk}^{+}\right)$supE44 thi-1 recA1 gyrA relA1 f80dlacZDM15D (lacZYA-argF) U169 & Invitrogen \\
\hline \multicolumn{3}{|c|}{ 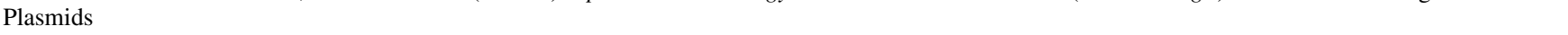 } \\
\hline pK18mob & $\mathrm{Km}^{\mathrm{r}}$,RP4Mob, mobilizable cloning vector & Schafer et al. 1994 \\
\hline pCR-Blunt II-TOPO & Cloning vector, lac $\mathrm{Z}^{\prime}, \mathrm{Km}^{\mathrm{r}}$ & Invitrogen \\
\hline pMP2464 & pBBR1MCS5 derivative; $\mathrm{EGFP}^{+}, \mathrm{Gm}^{\mathrm{R}}$ & Stuurman et al. 2000 \\
\hline pYT1 & pCR-Blunt II-TOPO + 607-bp PCR amplified fragment of yapH gene from BXO43 genomic DNA & This work \\
\hline pYM1 & pK18mob + 607-bp fragment of yapH (from pYT1) cloned into EcoRI site of pK18mob & This work \\
\hline pBM1 & $\begin{array}{l}\text { pK18mob + 451-bp PCR amplified fragment of } x a d B \text { gene from BXO43 genomic DNA cloned into } \\
\text { SmaI site of pK18mob }\end{array}$ & This work \\
\hline pQT1 & pCR-Blunt II-TOPO + 613 bp of PCR amplified fragment of pilQ gene from BXO43 & This work \\
\hline pQM1 & pK18mob + 613-bp fragment of pilQ (from pQT1) cloned into EcoRI site of pK18mob & This work \\
\hline \multicolumn{3}{|c|}{1} \\
\hline M13F & 5' GTAAAACGACGGCCAG & This work \\
\hline M13R & 5' CAGGAAACAGCTATGAC & This work \\
\hline PQ1F & 5' GCAGCTGATCGCCGAGGAGTCCAAT & This work \\
\hline PQ1R & 5' ACCACTGAGAATGCCGCGACCTGTC & This work \\
\hline PQ2F & 5' GGCGAGCCTGGCGGTGTCCAAAAT & This work \\
\hline PQ2R & 5' CGGGTTGCGCTAGCCACACGGA & This work \\
\hline YH1F & 5' TCGTCAATTGCCGGCCCTGGTGGTA & This work \\
\hline YH1R & 5' CTGAAAGCCCACCCGCCCGTTGAT & This work \\
\hline $\mathrm{YH} 2 \mathrm{~F}$ & 5' ATGGGGCGCGTCTGTTTCTGCTCA & This work \\
\hline YH2R & 5' GCTACCCGCACCCATCGAAACACT & This work \\
\hline $\mathrm{XB1F}$ & 5' CGCGCCATGCTCACCCTCCTGTTT & This work \\
\hline XB1R & 5' ACTGGCTGGCCTCGGTGGAATCCT & This work \\
\hline $\mathrm{XB} 2 \mathrm{~F}$ & 5' GCAGCGCCAGCCACGTAGAGAAAC & This work \\
\hline $\mathrm{XB} 2 \mathrm{R}$ & 5' ACGCATCGAGCTGGCCCTTGTTGAC & This work \\
\hline
\end{tabular}

${ }^{\mathrm{y}}$ Bacterial strains of Xanthomonas oryzae pv. oryzae and Escherichia coli and oligonucleotide primers.

${ }^{\mathrm{z}} \mathrm{Rf}^{\mathrm{r}}, \mathrm{Km}^{\mathrm{r}}$, and $\mathrm{Gm}^{\mathrm{r}}$ indicate resistance to rifampicin, kanamycin, and gentamicin, respectively; EGFP ${ }^{+}$indicates that cells express enhanced green fluorescent protein; $\mathrm{PCR}=$ polymerase chain reaction. For primers, $\mathrm{A}=$ adenosine, $\mathrm{T}=$ thymine, $\mathrm{G}=\mathrm{guanosine}$, and $\mathrm{C}=$ cytosine . 
In the present study, the most significant phenotype of a pilQ $Q^{-}$mutant $(\mathrm{BXO} 2101)$ was the reduction in virulence following wound inoculation. The length of the lesions formed by the pil $Q^{-}$mutant was only approximately $50 \%$ of the length of the lesions caused by the wild-type strain. The pil $Q^{-}$mutant also exhibited a very significant reduction in in planta migration. These observations clearly indicate that the PilQ protein and, hence, type IV pilus is required for optimum virulence of $X$. oryzae pv. oryzae when it is growing or migrating within the xylem vessels. Consistent with these findings, Lim and associates (2008) have recently reported that a pil $Q^{-}$mutant of $X$. oryzae pv. oryzae is virulence deficient following wound inoculation. In contrast, a mutation in the pilQ gene does not appear to affect leaf attachment or entry of $X$. oryzae $\mathrm{pv}$. oryzae. The role of type IV pilus in promoting infection upon surface inoculation of rice leaves is not very clear. In two of four experiments, the infection efficiency of the pilQ $Q^{-}$mutant (BXO2101) was equivalent to that of the wild-type strain. In the other two experiments, the same mutant exhibited a reduction in infection efficiency compared with the wild-type strain. However, in all four experiments, the lesion lengths of the pil $Q^{-}$mutant (following infection by surface inoculation) were approximately half of the lesion lengths of the wild-type strain (data not shown). This is consistent with the results from the wound inoculation experiments (as discussed above), which indicate that $\mathrm{BXO} 2101$ is deficient for growth or migration within the xylem vessels.

The infection efficiency following surface inoculation was always reduced for a $x a d A^{-}$mutant compared with the wild-type strain. However, variable results were observed when this method of inoculation was used with the $x^{-} a d B^{-}, y a p H^{-}$, and pil $Q^{-}$mutants. We speculate that successful infection following this method of inoculation is dependent on the efficiency of

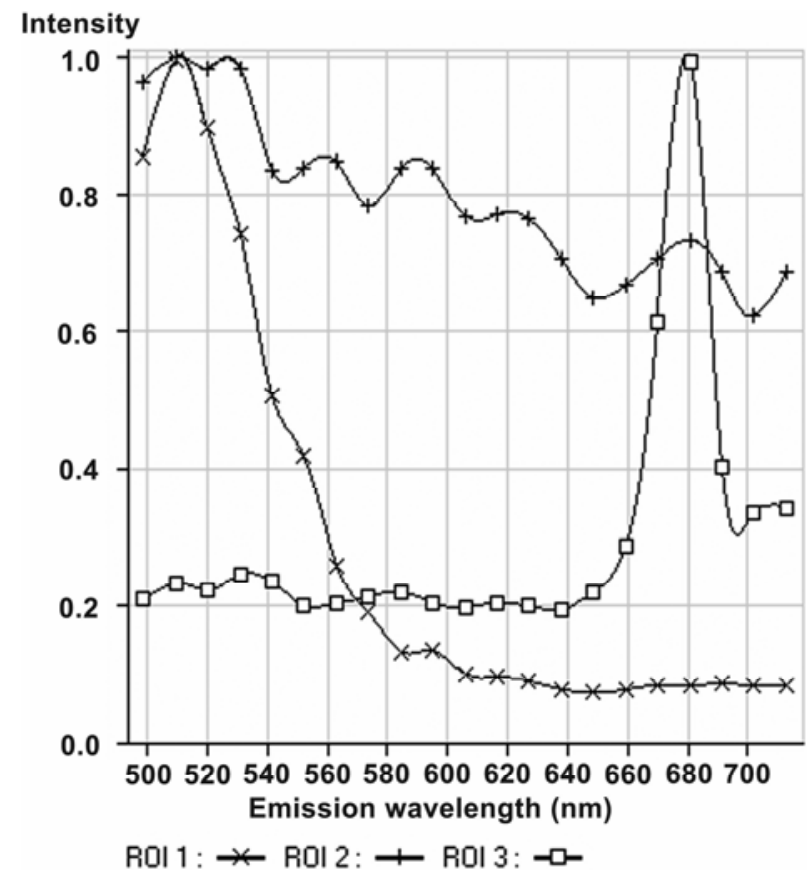

Fig. 9. Emission fingerprinting of enhanced green fluorescent protein (EGFP) fluorescence and rice leaf autofluorescence using confocal microscopy. At excitation maximum of $488 \mathrm{~nm}$ (argon laser), EGFP exhibits a specific emission maximum at $510 \mathrm{~nm}$. The regions of the leaf showing green autofluorescence exhibit several emission maxima, which are spread across the spectrum without following any specific pattern. Red autofluorescence of rice leaves exhibits a sharp emission maximum at $680 \mathrm{~nm}$. ROI 1: EGFP fluorescence; ROI 2: leaf green autofluorescence; ROI 3: leaf red autofluorescence. attachment and entry as well as other factors, such as the ability to ward off plant defense responses. We further speculate that the latter factors are subject to variables that we have been unable to control and also that the effect of this variation was magnified by the limited numbers of leaves (10 to 20$)$ that we used for infection with each bacterial strain. The confocal analysis indicates that bacteria are able to enter each and every infected leaf within $1 \mathrm{~h}$ of infection. However, even for the wild-type strain, the efficiency of symptom development following surface inoculation is no higher than 40 to $60 \%$. This suggests the possibility that the bacteria are up against a very powerful host innate immune response as they enter the hydathodal cavity. Consistent with this possibility is a recent report which indicates that hydathodal exudates of uninfected barley plants are enriched for pathogenesis-related proteins (Grunwald et al. 2003).

In summary, our results indicate that the XadA and XadB proteins are involved in promoting initial leaf attachment or entry. The YapH protein is not as important as the XadA protein in promoting either leaf attachment or entry or infection following surface inoculation but is more important than either the XadA or XadB proteins in promoting growth or migration within xylem vessels. The PilQ protein and, hence, type IV pilus appear to be much more important than either the XadA, $\mathrm{XadB}$, or YapH proteins in promoting growth or migration within xylem vessels; however, its role in the initial stages of leaf attachment and entry appears to be minimal. In vitro adhesion assay on glass surface does not show any phenotype of the mutants that is distinct from the wild-type $X$. oryzae pv. oryzae. This suggests that either there is functional redundancy or some additional functions besides those, which have been mutated in this study, are involved in promoting adherence to the in vitro surface.

Overall, the results of this study indicate that several adhesin-like functions are involved in promoting virulence of $X$. oryzae pv. oryzae on rice. However, each of the mutations isolated in this study has only a partial effect on virulence. It has been well documented that animal-pathogenic bacteria employ multiple adhesins to attach to host tissues, and mutations in genes for individual adhesins cause partial loss of virulence (Atherton 2006; Dunne 2002; Henderson and Nataro 2001; Jacques and Paradis 1998; Ofek et al. 2003; Rhem et al. 2000; Whittaker et al. 1996). Therefore, it is possible that the partial loss of virulence associated with each of the mutations studied here is due to functional redundancy among the concerned proteins (as indicated for the XadA and XadB proteins in the leaf attachment or entry assay). Alternatively, there might be other as yet uncharacterized adhesin-like functions of $X$. oryzae pv. oryzae. Nuccio and Baumler (2007) have suggested that xanthomonads, including $X$. oryzae pv. oryzae, have a full complement of genes for an atypical type I fimbrial system or chaperon-usher pathway. It would be interesting to examine the role of this gene cluster in promoting leaf colonization as well as virulence of $X$. oryzae pv. oryzae. Also, it would be interesting to determine the phenotypes of additional double mutants as well as triple and quadruple mutants for the adhesin-like functions that have been characterized in this study.

\section{MATERIALS AND METHODS}

Bacterial strains, plasmids, and oligonucleotide primers.

All bacterial strains, plasmids, and oligonucleotide primers used in this study are listed in Table 4. Escherichia coli strains were grown in Luria-Bertani medium (Miller 1992) at $37^{\circ} \mathrm{C}$ and $X$. oryzae pv. oryzae cultures were grown in PS medium at $28^{\circ} \mathrm{C}$ (Ray et al. 2002). Antibiotics (Sigma-Aldrich, St. Louis) which were used in this study are as follows: rifampicin (50 
$\mu \mathrm{g} / \mathrm{ml})$, kanamycin $(15 \mu \mathrm{g} / \mathrm{ml}$ for $X$. oryzae pv. oryzae and 50 $\mu \mathrm{g} / \mathrm{ml}$ for $E$. coli), gentamicin $(7.5 \mu \mathrm{g} / \mathrm{ml})$, spectinomycin $(50$ $\mu \mathrm{g} / \mathrm{ml})$, cephalexin $(10 \mu \mathrm{g} / \mathrm{ml})$, cycloheximide $(100 \mu \mathrm{g} / \mathrm{ml})$, and tetracycline $(5 \mu \mathrm{g} / \mathrm{ml})$.

\section{In silico analysis of the genome or gene sequences.}

The in silico analysis of genomes or genes were carried out by Internet-based servers.

\section{Development of an assay for monitoring early stages of leaf attachment or entry of $X$. oryzae pv. oryzae based on confocal laser scanning microscopy.}

$X$. oryzae pv. oryzae cells harboring pMP2464 (expressing EGFP) were inoculated in PS medium $(4 \mathrm{ml})$ supplemented with gentamicin and rifampicin and grown to early stationary phase, pelleted down, washed, and resuspended in sterile miliQ water at a concentration of $10^{9}$ cells $/ \mathrm{ml}$. Fresh leaves (with intact and uninjured tips) from 30- to 40-day-old rice plants (X. oryzae pv. oryzae-susceptible cv. TN-1) were detached and dipped for an hour at $28^{\circ} \mathrm{C}$ in bacterial suspension up to a distance of approximately $3 \mathrm{~cm}$ from the tip. Leaf pieces extending up to a distance of 2 to $3 \mathrm{~cm}$ from the leaf tip were cut with scissors, vortexed in water for 10 to $15 \mathrm{~s}$, and observed in a confocal microscope under $\times 63$ water objective (LSM 510, meta; Carl Zeiss, Germany). The excitation maximum was at $488 \mathrm{~nm}$ (argon laser) and the emission maxima were observed in band pass (BP) 510 to $530 \mathrm{~nm}$ (for EGFP fluorescence) and BP 650 to $710 \mathrm{~nm}$ (for red autofluorescence of leaf). Occasional leaf green autofluorescence was also observed in emission maximum at BP 510 to 530nm. Emission fingerprinting was performed to distinguish between EGFP fluorescence and leaf green autofluorescence (Fig. 9). Although EGFP fluorescence showed a sharp peak at $510 \mathrm{~nm}$, there were several peaks in the emission spectra of leaf green autofluorescence. The morphological features of EGFP fluorescence and leaf green autofluorescence also showed marked differences. Whereas the EGFP fluorescence was stronger and corresponded to a typical rod-shaped bacterium, leaf green autofluorescence was often diffused, patchy, and without any distinct morphological features.

Optical sections of the $X$. oryzae pv. oryzae-inoculated leaves were taken in a plane parallel to the leaf surface. Scanning of the leaves was done in three successive regions, each with a field area of approximately 200 by $200 \mu \mathrm{m}$ (along the $\mathrm{X}, \mathrm{Y}$ axis) and up to the first $600 \mu \mathrm{m}$ from the very tip of the leaf and for a depth of up to a maximum of $90 \mu \mathrm{m}$ from the dorsal surface of the leaf, with 1- to 3- $\mu \mathrm{m}$ thickness of each optical section. The total number of EGFP spots in this region of the leaf was counted and considered to be representative of the total number of bacterial cells associated with the leaf. For each strain, at least three leaves were observed and the mean number of cells per leaf was calculated. Each set of experiments was carried out at least three times. For each gene that was mutated in this study, at least two independently isolated mutants were used. The images were analyzed using the software Zeiss LSM image examiner (Carl Zeiss).

\section{Generation of mutations}

in $x a d B, y a p H$, and pil $Q$ genes of $X$. oryzae pv. oryzae.

Mutations in $x a d B, y a p H$, and pilQ genes of $X$. oryzae pv. oryzae $\mathrm{BXO} 43$ were generated by integration of recombinant pK18mob plasmid through homologous recombination. An internal fragment of the gene that is to be mutated was polymerase chain reaction (PCR) amplified from BXO43 genomic DNA and cloned in pK18mob plasmid. Biparental matings were set up between E. coli S17-1 harboring recombinant pK18mob plasmid and $X$. oryzae pv. oryzae strains. Integration events of the recom- binant plasmid into the recipient chromosome were isolated by selection for kanamycin resistance. Gene disruption was confirmed by PCR and sequencing of the PCR products. This process resulted in nonpolar mutations when the transcriptional orientation of the gene of interest and the promoter of lacZ gene in pK18mob were in the same direction (Wei et al. 2007; Windgassen et al. 2000). For each mutant, at least two independent integration events of the plasmid were studied in order to make sure that any phenotypes associated with the mutations were due to the gene disruption and not due to a second site mutation that had coincidentally occurred.

Isolation of pilQ mutations. An intragenic fragment of the pilQ gene (613 bp, 678 to $1,290 \mathrm{bp}$ ) was PCR amplified using the gene-specific PQ1F/PQ1R primer pair (Table 4) and cloned in pCR-Blunt II-TOPO vector (Invitrogen Inc., Carlsbad, CA, U.S.A.) to generate the plasmid pQT1. The insert in pQT1 was released by digestion with EcoRI and cloned in the EcoRI site of $\mathrm{pK} 18 \mathrm{mob}$ to generate the plasmid pQM1. This clone (pQM1) was then introduced into the S17-1 strain of E. coli by electroporation. Biparental matings between the recipient $X$. oryzae pv. oryzae strain and donor S17-1 strain were set up and pilQ mutants were obtained by selecting for kanamycin resistance. Gene disruption was confirmed by PCR using combinations of gene-specific primers (PQ2F/PQ2R; located in chromosomal regions that flank the insert sequence cloned in pQM1) and vector-specific M13F/M13R primer pairs and sequencing of the PCR products. In the pQM1 clone, the transcriptional orientation of the lacZ promoter of $\mathrm{pK} 18 \mathrm{mob}$ and pilQ gene fragment were in the same direction; therefore, it is expected, as indicated by Wei and associates (2007) and Windgassen and associates (2000), that the mutation caused by pQM1 integration will not be polar on any downstream gene that might be co-transcribed with pilQ. Moreover, the gene immediately downstream of pilQ encodes a transposase and is in the opposite transcriptional orientation. Therefore, it is unlikely that the phenotypes associated with the pilQ mutation are due to a polar effect on transcription of a downstream gene.

Isolation of xadB mutations. An intragenic fragment of the $x a d B$ gene (451 bp, 226 to 676 bp) was PCR amplified from BXO43 genomic DNA by using the gene-specific primer pair $\mathrm{XB} 1 \mathrm{~F} / \mathrm{XB} 1 \mathrm{R}$ and cloned in the SmaI site of pK18mob to generate plasmid $\mathrm{pBM} 1$. Biparental matings between the recipient $X$. oryzae pv. oryzae strains (wild-type strain $\mathrm{BXO} 43$ and $x_{a d A^{-}}$mutant $\mathrm{BXO837)}$ and a donor S17-1 strain carrying pBM1 were then set up and $x a d B^{-}$mutants were isolated by selecting for kanamycin resistance. Gene disruption was confirmed by PCR using combinations of gene-specific primers (XB2F/XB2R; located in chromosomal regions that flank the insert sequence cloned in pBM1) and vector-specific M13F/M13R primer pair and sequencing of the PCR products. In the pBM1 clone, the transcriptional orientation of the $l a c Z$ promoter of $\mathrm{pK} 18 \mathrm{mob}$ and the cloned $x a d B$ gene fragment are in the same direction; therefore, it is expected that the gene disruption caused by pBM1 integration will not be polar on a downstream protease gene (XOO0680) (Lee et al. 2005) which is in the same transcriptional orientation as $x a d B$.

Isolation of yapH mutations. An intragenic fragment of the yapH gene (607 bp, 156 to $762 \mathrm{bp}$ ) was PCR amplified from BXO43 genomic DNA using the gene-specific primer pair YH1F/YH1R and cloned in pCR-Blunt II-TOPO vector to obtain the clone pYT1. Following EcoRI digestion of pYT1, the released insert was cloned in the EcoRI site of pK18mob, resulting in the pYM1 clone. Gene disruptions were obtained by selection for kanamycin-resistant colonies in biparental matings set up between the recipient $X$. oryzae pv. oryzae strain and a donor S17-1 strain of E. coli harboring the pYM1 
clone. Gene disruption was confirmed by PCR using combinations of gene-specific primers (YH2F/YH2R; located in chromosomal regions that flank the insert sequence cloned in pYT1) and vector-specific M13F/M13R primer pair and sequencing of the PCR products. The gene $(\operatorname{nod} W)$ that is immediately downstream of $y a p H$ is in the opposite transcriptional orientation (Lee et al. 2005; Ochiai et al. 2005; Salzberg et al. 2008) and, therefore, it is unlikely that the phenotypes associated with yapH gene disruption are due to a polar effect.

\section{Mobilization of pMP2464 to $X$. oryzae pv. oryzae strains.}

The plasmid pMP2464 encodes EGFP under the control of the lac promoter (Stuurman et al. 2000). It was introduced in the S17-1 strain of E. coli by electroporation, and biparental matings were set up between $X$. oryzae pv. oryzae strains and the S17-1 strain harboring pMP2464. The transconjugants were selected on medium supplemented by gentamicin and rifampicin and the expression of EGFP was confirmed using a fluorescence microscope.

\section{Virulence assays.}

Virulence assays were carried out by two different methods, wound inoculation and surface inoculation. Wound inoculation was performed by the leaf-clipping method (Kauffman et al. 1973). Bacterial cultures were grown in PS medium (3 ml) supplemented with rifampicin until the early stationary phase, and pelleted down by centrifugation, and resuspended in sterile miliQ water $(3 \mathrm{ml})$ at a concentration of approximately $10^{9}$ cells/ml. Surgical scissors dipped in these bacterial suspensions were used to clip the leaf tips of greenhouse grown, 30to 40-day-old rice cv. TN-1 plants. Lesion lengths were measured 7,10, and 14 days after inoculation. For each strain, 10 to 15 leaves were inoculated per experiment and each experiment was repeated at least three times.

Assays for epiphytic infection by surface inoculation were carried out as described previously (Ray et al. 2002). Bacterial cultures were grown to early stationary phase in PS medium $(30 \mathrm{ml})$ supplemented with rifampicin and pelleted down by centrifugation. The pellets were resuspended in sterile miliQ water $(10 \mathrm{ml})$. These bacterial suspensions (approximately $3 \times 10^{9}$ cells $/ \mathrm{ml}$ ) were used to inoculate leaves (whose tips were uninjured) of 30- to 40-day-old rice plants (TN-1) up to a distance of approximately 4 to $5 \mathrm{~cm}$. Rice plants were maintained under conditions of high humidity (in specially built chambers in the greenhouse) for $24 \mathrm{~h}$ before inoculation. After inoculation, the plants were kept in the same humidity chambers for the next 7 days and then placed outside the chamber but within the greenhouse. Three weeks after inoculation (21 days), the total number of leaves showing disease lesions was counted and the percentage of infection was calculated against the total number of leaves inoculated. For each strain, 10 to 20 leaves were inoculated per experiment and each experiment was repeated at least three times.

\section{Migration of $X$. oryzae pv. oryzae inside the leaves.}

The conditions for growth of $X$. oryzae pv. oryzae strains and inoculation of rice leaves were as described earlier for wound inoculation. The assay for bacterial migration was performed as described previously with certain modifications (Chatterjee and Sonti 2002). The inoculated leaves were detached from the plants 4 days after inoculation and surface sterilized in $0.5 \%$ sodium hypochlorite solution (Loba Chemie, Mumbai, India). Following repeated washing in sterile water, leaves were cut into approximately $1-\mathrm{cm}$ pieces (along the width) from the bottom of the leaf to the top (site of inoculation) by sterile scissors and incubated on PS agar media supplemented with antibiotics (rifampicin, cycloheximide, and cephalexin) at $28^{\circ} \mathrm{C}$. After 1 to 3 days, colonies were formed by the bacterial ooze from the cut ends of rice leaf pieces and the distance of bacterial migration was estimated. In each experiment for each strain, at least three leaves were inoculated and the experiment was repeated at least three times.

\section{In vitro adhesion assay.}

$X$. oryzae pv. oryzae strains were grown in PS medium (3 $\mathrm{ml})$ to early stationary phase, pelleted down, washed, and resuspended in sterile miliQ water $(3 \mathrm{ml})$ up to density of $10^{9}$ cells $/ \mathrm{ml}$. These resuspended bacterial cells were used to make bacterial smears on the glass slides (using $200 \mu \mathrm{l}$ of each culture) and kept under conditions of high humidity at $28^{\circ} \mathrm{C}$ for $1 \mathrm{~h}$. The slides were rinsed in sterile water, air dried, and observed in an AFM (Bioscope AFM with Nanoscope IV controller; Digital Imaging, Santa Barbara, CA, U.S.A.). For imaging, the tapping mode was selected and a silicon nitride probe tip was used. For each strain, at least three randomly selected regions were observed and each experiment was repeated at least three times.

\section{Statistical analysis.}

Student's two-tailed $t$ test for independent means was performed using the Graphpad software as well as manually, and $\chi^{2}$ analysis was performed using Microsoft Excel as well as manually.

\section{ACKNOWLEDGMENTS}

A. Das was supported by a grant from the Council of Scientific and Industrial Research (CSIR), Government of India. We acknowledge the help of S. Singh for imaging in atomic force microscopy, N. Nagesh for DNA sequencing, S. Bhattacharyya and C. Chatterjee for statistical analysis, and the valuable suggestions of two anonymous reviewers.

\section{LITERATURE CITED}

Chatterjee, S., and Sonti, R. V. 2002. rpfF mutants of Xanthomonas oryzae pv. oryzae are deficient for virulence and growth under low iron conditions. Mol. Plant-Microbe Interact. 15:463-471.

Drake, S. L., and Koomey, M. 1995. The product of the pilQ gene is essential for the biogenesis of type IV pili in Neisseria gonorrhoeae. Mol. Microbiol. 18:975-986.

Dunne, W M., Jr. 2002. Bacterial adhesion: Seen any good biofilms lately? Clin. Microbiol. Rev. 15:155-166.

Feil, H., Feil, W. S., and Lindow, S. E. 2007. Contribution of fimbrial and afimbrial adhesins of Xylella fastidiosa to attachment to surfaces and virulence to grape. Phytopathology 97:318-324.

Grunwald, I., Rupprechta, I., Schusterb, G., and Kloppstecha, K. 2003. Identification of guttation fluid proteins: the presence of pathogenesisrelated proteins in non-infected barley plants. Physiol. Plant. 119:192202.

Henderson, I. R., and Nataro, J. P. 2001. Virulence functions of autotransporter proteins. Infect. Immun. 69:1231-1243.

Hugouvieux, V., Barber, C. E., and Daniels, M. J. 1998. Entry of Xanthomonas campestris pv. campestris into hydathodes of Arabidopsis thaliana leaves: a system for studying early infection events in bacterial pathogenesis. Mol. Plant-Microbe Interact. 6:537-543.

Jacques, M., and Paradis, S.-E. 1998. Adhesin-receptor interactions in Pasteurellaceae. FEMS (Fed. Eur. Microbiol. Soc.) Microbiol. Rev.22:4559.

Kang, Y., Liu, H., Genin, S., Schell, M. A., and Denny, T. P. 2002. Ralstonia solanacearum requires type 4 pili to adhere to multiple surfaces and for natural transformation and virulence. Mol. Microbiol. 2:427-437.

Kauffman, N. T., Reddy, A. P. K., Hsieh, S. P. Y., and Merca, S. D. 1973. An improved technique for evaluation of resistance of rice varieties to Xanthomonas oryzae. Plant Dis. Rep. 57:537-541.

Lee, B. M., Park, Y. J., Park, D. S., Kang, H. W., Kim, J. G., Song, E. S. Park, I. C., Yoon, U. H., Hahn, J. H., Koo, B. S., Lee, G. B., Kim, H., Park, H. S., Yoon, K. O., Kim, J. H., Jung, C. H., Koh, N. H., Seo, J. S., and Go, S. J. 2005. The genome sequence of Xanthomonas oryzae pathovar oryzae KACC10331, the bacterial blight pathogen of rice. Nucleic Acids Res. 33:577-586. 
Lim, S.-H., So, B.-H., Wang, J.-C., Song, E.-S., Park, Y.-J., Lee, B.-M., and Kang, H.-W. 2008. Functional analysis of pilQ gene in Xanthomonas oryzae pv. oryzae, bacterial blight pathogen of rice. J. Microbiol. 46:214-220.

Liu, H., Kang, Y., Genin, S., Schell, M. A., and Denny, T. P. 2001. Twitching motility of Ralstonia solanacearum requires a type IV pilus system. Microbiology 147:3215-3229.

Matthysse, A. G. 1983. Role of bacterial cellulose fibrils in Agrobacterium tumefaciens infection. J. Bacteriol. 154:906-915.

Meng, Y., Li, Y., Galvani, C. D., Hao, G., Turner, J. N., Burr, T. J., and Hoch, H. C. 2005. Upstream migration of Xylella fastidiosa via pilusdriven twitching motility. J. Bacteriol. 187:5560-5567.

Mew, T. W., Mew, I. C., and Huang, J. S. 1984. Scanning electron microscopy of virulent and avirulent strains of Xanthomonas campestris pv. oryzae on rice leaves. Phytopathology 74:635-641.

Miller, J. H. 1992. A Short Course in Bacterial Genetics: A Laboratory Manual for Escherichia coli and Related Bacteria. Cold Spring Harbor Laboratory Press, Cold Spring Harbor, NY, U.S.A.

Nuccio, S. P., and Baumler, A. J. 2007. Evolution of the chaperon/usher assembly pathway: fimbrial classification goes Greek. Microbiol. Mol. Biol. Rev. 71:551-575.

Ochiai, H., Inoue, Y., Takeya, M., Sasaki, A., and Kaku, H. 2005. Genome sequence of Xanthomonas oryzae pv. oryzae suggests contribution of large numbers of effector genes and insertion sequences to its race diversity. Jpn. Agric. Res. Q. 39:275-287.

Ofek, I., Hasty, D. L., and Sharon, N. 2003. Anti-adhesion therapy of bacterial diseases: prospects and problems. FEMS (Fed. Eur. Microbiol. Soc.) Immunol. Med. Microbiol. 38:181-191.

Ojanen-Reuhs, T., Kalkkinen, N., Westerlund-Wikstrom, B., van Doorn, J., Haahtela, K., Nurmiaho-Lassila, E. L., Wengelink, K., Bonas, U., and Korhonen, T. K. 1997. Characterization of the fimA gene encoding bundle-forming fimbriae of the plant pathogen Xanthomonas campestris pv. vesicatoria. J. Bacteriol. 179:1280-1290.

Puvanesarajah, V., Schell, F. M., Stacey, G., Douglas, C. J., and Nester, E. W. 1985. Role for 2-linked-beta-D-glucan in the virulence of Agrobacterium tumefaciens. J. Bacteriol. 164:102-106.

Ray, S. K., Rajeswari, R., Sharma, Y., and Sonti, R. V. 2002. A high molecular weight outer membrane protein of Xanthomonas oryzae pv. oryzae exhibits similarity to non-fimbrial adhesins of animal pathogenic bacteria and is required for optimum virulence. Mol. Microbiol. 46:637-647.

Reuhs, B. L., Kim, J. S., and Matthysse, A. G. 1997. Attachment of Agrobacterium tumefaciens to carrot cells and Arabidopsis wound sites is correlated with the presence of a cell-associated, acidic polysaccharide. J. Bacteriol. 179:5372-5379.

Rhem, M. N., Lech, E. M., Patti, J. M., McDevitt, D., Hook, M., Jones, D. B., and Wilhelmus, K. R. 2000. The collagen-binding adhesin is a virulence factor in Staphylococcus aureus Keratitis. Infect. Immun. 68:3776-3779.

Roine, E., Raineri, D. M., Romantschuk, M., Wilson, M., and Nunn, D. N. 1998. Characterization of type IV pilus genes in Pseudomonas syringae pv. tomato DC3000. Mol. Plant-Microbe Interact. 11:1048-1056.

Rojas, C. M., Ham, J. H., Deng, W. L., Doyle, J. J., and Collmer, A. 2002. HecA, a member of a class of adhesins produced by diverse pathogenic bacteria, contributes to the attachment, aggregation, epidermal cell killing, and virulence phenotypes of Erwinia chrysanthemi EC16 on Nicotiana clevelandii seedlings. Proc. Natl. Acad. Sci. U.S.A. 99:13142-13147.

Romantschuk, M., and Bamford, D. H. 1986. The causal agent of halo blight in bean, Pseudomonas syringe pv. phaseolicola, attaches to stomata via its pili. Microb. Pathog. 1:139-148.

Salzberg, S. L. Sommer, D. D., Schatz, M. C., Phillippy, A. M., Rabinowicz, P. D., Tsuge, S., Furutani, A., Ochiai, H., Delcher, A. L., Kelley, D.
Madupu, R., Puiu, D., Radune, D., Shumway, M., Trapnell, C., Aparna, G., Jha, G., Pandey, A., Patil, P.B., Ishihara, H., Meyer, D.F., Szurek, B., Verdier, V., Koebnik, R., Dow, J. M., Ryan, R. P., Hirata, H., Tsuyumu, S., Won Lee, S., Ronald, P. C., Sonti, R. V., Van Sluys, M. A., Leach, J. E., White, F. F., and Bogdanove, A. J. 2008. Genome sequence and rapid evolution of the rice pathogen Xanthomonas oryzae pv. oryzae PXO99A. BMC Genomics 9:204.

Schafer, A., Tauch, A., Jager, W., Kalinowski, J., Thierbach, G., and Puhler, A. 1994. Small mobilizable multi-purpose cloning vectors derived from the Escherichia coli plasmids pK18 and pK19: selection of defined deletions in the chromosome of Corynebacterium glutumicum. Gene 145:69-73.

Simon, R., Priefer, U., and Puhler, A. 1983. A broad host range mobilization system for in vivo genetic engineering: transposon mutagenesis in gram-negative bacteria. Bio/Technology 1:784-794.

Smit, G., Logman, T. J. J., Boerrigter, M. E. T. I., Kijne, J. W., and Lugtenberg, B. J. J. 1989. Purification and partial characterization of the Rhizobium leguminosarum biovar viciae $\mathrm{Ca}^{2+}$-dependent adhesin, which mediates the first step in attachment of the cells of the family Rhizobiaceae to plant root hair tips. J. Bacteriol. 171:4054-4062.

Soto, G. E., and Hultgren, S. J. 1999. Bacterial adhesins: common themes and variations in architecture and assembly. J. Bacteriol. 181:10591071.

Stuurman, N., Bras, C. P., Schlaman, H. R. M., Wijfjes, A., Bloemberg, G., and Spaink, H. P. 2000. Use of green fluorescent protein color variants expressed on stable broad-host-range vectors to visualize rhizobia interacting with plants. Mol. Plant-Microbe Interact. 13:1163-1169.

Styer, K. L., Hopkins, G. W., Bartra, S. S., Plano, G. V., Frothingham, R., and Aballay, A. 2005. Yersinia pestis kills Caenorhabditis elegans by a biofilm-independent process that involves novel virulence factors. EMBO (Eur. Mol. Biol. Organ.) Rep. 6:992-997.

Tabei, H. 1967. Anatomical studies of rice plant affected with bacterial leaf blight. Ann. Phytopathol. Soc. Jpn. 33:12-16.

van Doorn, J., Boonekamp, P. M., and Oudega, B. 1994. Partial Characterization of fimbriae of Xanthomonas campestris pathovar hyacinthi. Mol. Plant-Microbe Interact. 7:334-344.

Vesper, S. J., and Bauer, W. D. 1986. Role of pili (fimbriae) in attachment of Bradyrhizobium japonicum to soybean roots. Appl. Environ. Microbiol. 52:134-141.

Wei, K., Tang, D.-J., He, Y.-Q., Feng, J.-X., Jiang, B.-L., Lu, G.-T., Chen, B., and Tang, J.-L. 2007. hpaR, a putative marR family transcriptional regulator, is positively controlled by $\mathrm{HrpG}$ and $\operatorname{HrpX}$ and involved in the pathogenesis, hypersensitive response, and extracellular protease production of Xanthomonas campestris pathovar campestris. J. Bacteriol. 189:2055-2062.

Whittaker, C. J., Klier, C. M., and Kolenbrander, P. E. 1996. Mechanisms of adhesion by oral bacteria. Annu. Rev. Microbiol. 50:513-552.

Windgassen, M., Urban, A., and Jaeger, K. E. 2000. Rapid gene inactivation in Pseudomonas aeruginosa. FEMS (Fed. Eur. Microbiol. Soc.) Microbiol. Lett. 193:201-205.

\section{AUTHOR-RECOMMENDED INTERNET RESOURCES}

National Center for Biotechnology Information website: www.ncbi.nlm.nih.gov

European Molecular Biology Laboratory European Bioinformatics Institute InterProScan website: www.ebi.ac.uk/InterProScan

J. Craig Venter Institute's The Comprehensive Microbial Resource home page: cmr.jcvi.org/tigr-scripts/CMR/CmrHomePage.cgi

MultAlin database: bioinfo.genotoul.fr/multalin/multalin.html

Graphpad software website: www.graphpad.com/quickcalcs/ttest1.cfm 